Published in final edited form as:

Transplantation. 2016 January ; 100(1): 91-102.

\title{
Eomesodermin ${ }^{10}$ CTLA4hi Alloreactive CD8+ Memory T Cells Are Associated With Prolonged Renal Transplant Survival Induced by Regulatory Dendritic Cell Infusion in CTLA4Ig-Treated Non- Human Primates
}

\author{
Mohamed B. Ezzelarab ${ }^{1}$, Lien Lu1, Hao Guo ${ }^{1}$, Alan F. Zahorchak ${ }^{1}$, William F. Shufesky ${ }^{1}$, \\ David K.C. Cooper ${ }^{1}$, Adrian E. Morelli ${ }^{1,2}$, and Angus W. Thomson ${ }^{1,2}$ \\ Mohamed B. Ezzelarab: ezzemb@upmc.edu; Lien Lu: lult@upmc.edu; Hao Guo: guoh@upmc.edu; Alan F. Zahorchak: \\ zahor@pitt.edu; William F. Shufesky: shufwj@upmc.edu; David K.C. Cooper: coopdk@upmc.edu; Adrian E. Morelli: \\ morelli@pitt.edu; Angus W. Thomson: thomsonaw@upmc.edu \\ ${ }^{1}$ Starzl Transplantation Institute, Department of Surgery, University of Pittsburgh School of \\ Medicine, Pittsburgh, PA \\ ${ }^{2}$ Department of Immunology, University of Pittsburgh School of Medicine, Pittsburgh, PA
}

\section{Abstract}

Background-Memory $\mathrm{T}$ cells (Tmem), particularly those resistant to costimulation blockade (CB), are a major barrier to transplant tolerance. The transcription factor Eomesodermin (Eomes) is critical for Tmem development and maintenance, but its expression by alloactivated $\mathrm{T}$ cells has not been examined in non-human primates.

Methods-We evaluated Eomes and co-inhibitory cytotoxic T lymphocyte antigen-4 (CTLA4) expression by alloactivated rhesus monkey T cells in the presence of CTLA4 immunoglobulin (Ig), both in vitro and in renal allograft recipients treated with CTLA4Ig, with or without regulatory dendritic cell (DCreg) infusion.

Results-In normal monkeys, $\mathrm{CD} 8^{+} \mathrm{T}$ cells expressed significantly more Eomes than $\mathrm{CD} 4^{+} \mathrm{T}$ cells. By contrast, $\mathrm{CD} 8^{+} \mathrm{T}$ cells displayed minimal CTLA4. Among T cell subsets, central Tmem $(\mathrm{Tcm})$ expressed the highest levels of Eomes. Notably, Eomes ${ }^{\mathrm{lo}} \mathrm{CTLA} 4 \mathrm{hi}$ cells displayed higher levels of CD25 and Foxp3 than Eomes ${ }^{\text {hi }}$ CTLA $4{ }^{\text {lo }} \mathrm{CD} 8^{+} \mathrm{T}$ cells. Following allostimulation, distinct proliferating Eomes ${ }^{\mathrm{lo}} \mathrm{CTLA} 44^{\mathrm{hi}}$ and Eomes ${ }^{\mathrm{hi}} \mathrm{CTLA} 44^{\mathrm{lo}} \mathrm{CD} 8^{+} \mathrm{T}$ cell populations were identified, with a high proportion of Tcm being Eomes ${ }^{\text {lo }} \mathrm{CTLA} 4{ }^{\text {hi }}$. CB with CTLA4Ig during allostimulation of $\mathrm{CD} 8^{+} \mathrm{T}$ cells reduced CTLA4 but not Eomes expression, significantly reducing Eomes ${ }^{\mathrm{lo}} \mathrm{CTLA} 4{ }^{\text {hi }}$ cells. After transplantation with $\mathrm{CB}$ and rapamycin, donor-reactive

Correspondence: Angus W. Thomson, PhD, DSc, (submitting author), University of Pittsburgh School of Medicine, 200 Lothrop Street, W1540 BST, Pittsburgh, PA 15261, thomsonaw@ upmc.edu or Mohamed B. Ezzelarab, MD, University of Pittsburgh School of Medicine, 200 Lothrop Street, E1551 BST, Pittsburgh, PA 15261, ezzemb@upmc.edu.

Authors contributions: M.B.E. participated in research design, writing of the paper, performance of the research and data analysis, H.G. and L.L. participated in performance of the research and data analysis, A.F.Z. participated in performance of the research, W.F.S. participated in performance of the research, D.K.C.C. participated in performance of the research and review of the paper, A.E.M. participated in research design and data analysis, A.W.T. participated in research design, data analysis and writing of the paper.

Disclosure: The authors disclose no conflicts of interest 
Eomes ${ }^{\text {lo }} \mathrm{CTLA} 4{ }^{\text {hi }} \mathrm{CD} 8{ }^{+} \mathrm{T}$ cells were reduced. However, in monkeys also given DCreg, absolute numbers of these cells were elevated significantly.

Conclusions-Low Eomes and high CTLA4 expression by donor-reactive CD8 ${ }^{+}$Tmem is associated with prolonged renal allograft survival induced by DCreg infusion in CTLA4Ig-treated monkeys. Prolonged allograft survival associated with DCreg infusion may be related to maintenance of donor-reactive Eomes ${ }^{\mathrm{lo}} \mathrm{CTLA} 4{ }^{\mathrm{hi}} \mathrm{Tcm}$.

\section{INTRODUCTION}

Induction of tolerance to organ allografts can be readily achieved in rodents by a variety of strategies. However, such approaches have proved unsuccessful in non-human primate (NHP) models and in clinical transplantation. Pre-existing alloreactive memory T cells (Tmem) are considered a major barrier to the induction of tolerance (1). In NHP, kidney allograft rejection is associated with the development of costimulation blockade (CB)resistant Tmem (2-4). Recent clinical testing of cytotoxic T lymphocyte Ag 4 (CTLA4) immunoglobulin (Ig) (belatacept), a chimeric fusion protein that blocks the B7-CD28 pathway, in a calcineurin inhibitor-free regimen, has resulted in an increased incidence of acute cellular rejection in renal transplant recipients $(5,6)$. There is also recent evidence that CTLA4Ig may prevent regulatory $\mathrm{T}$ cell (Treg)-dependent transplant tolerance in rodents (7, $8)$.

Alloreactive $\mathrm{CD} 8^{+}$Tmem are known to be more resistant to $\mathrm{CB}$ than $\mathrm{CD} 4^{+}$Tmem (9-12). Eomesodermin (Eomes) is a key transcription factor in $\mathrm{CD}^{+}$Tmem differentiation, fate and function $(13,14)$. It plays a critical role in the long-term survival of antigen (Ag)-specific central memory T cells (Tcm) (15). Significantly, however, the role of Eomes in the differentiation, regulation and maintenance of donor-specific Tmem in allograft recipients has not been examined.

Using a robust, rhesus monkey model, we have reported recently (16) that a single infusion of donor-derived regulatory dendritic cells (DCreg), one week before transplant, together with CTLA4Ig and tapered rapamycin maintenance monotherapy, can significantly prolong renal allograft survival. This therapeutic effect of DCreg is associated with increased CD4 ${ }^{+}$ Treg to $\mathrm{CD} 8^{+}$Tmem ratios in peripheral blood and with upregulation of co-inhibitory CTLA4 (CD152) and programmed death-1 (PD1; CD279) by Tmem following their stimulation by donor but not third party Ag. Together, these findings suggest attenuation of donor-specific Tmem responses in DCreg recipients (17).

It has been reported that CTLA4 may reduce Eomes expression by CD8 ${ }^{+} \mathrm{T}$ cells (18). Here, we examined the expression of Eomes and CTLA4 by normal and allostimulated monkey Tmem and by Tmem in CTLA4Ig-treated renal allograft recipients, without or with DCreg infusion. We found that $\mathrm{CD}^{+} \mathrm{T}$ cells express higher levels of Eomes, but lower levels of CTLA4 compared to $\mathrm{CD} 4^{+} \mathrm{T}$ cells, in which population Tcm displayed the highest levels of Eomes. Additionally, Eomes ${ }^{\text {lo }} \mathrm{CTLA} 44^{\text {hi }} \mathrm{CD} 8{ }^{+} \mathrm{T}$ cells expressed higher CD25 and Foxp3 levels than Eomes ${ }^{\text {hi CTLA } 4}{ }^{\text {lo }} \mathrm{CD} 8^{+} \mathrm{T}$ cells. CB with CTLA4Ig significantly reduced CTLA4, but not Eomes expression by alloreactive $\mathrm{T}$ cells in vitro. This was associated with reduction in the alloreactive Eomes ${ }^{\text {lo }} \mathrm{CTLA} 44^{\text {hi }}$ but not the Eomes ${ }^{\text {hi }} \mathrm{CTLA} 44^{\text {lo }}$ subpopulation. 
Our data also reveal that combined CTLA4Ig and pre-transplant DCreg infusion is associated with low Eomes and high CTLA4 expression by donor-reactive $\mathrm{CD} 8^{+} \mathrm{Tcm}$, consistent with attenuation of donor-specific Tmem and improved graft survival in CBtreated graft recipients.

\section{RESULTS}

\section{CD8+ Tmem Express High Eomes and Minimal CTLA4 Levels Compared to CD4+ Tmem in Normal Rhesus Monkeys}

Eomes is a T-box transcription factor that plays a key role in the differentiation of Tmem, particularly Ag-specific Tcm (15). First, we examined the expression of Eomes by normal monkey peripheral blood $\mathrm{CD} 4^{+}$and $\mathrm{CD} 8^{+} \mathrm{T}$ cells (Fig. 1A). $\mathrm{CD} 8^{+} \mathrm{T}$ cells expressed significantly higher levels (approx. 5-fold) than $\mathrm{CD}^{+} \mathrm{T}$ cells. Next, we evaluated Eomes expression by naïve and memory subsets of $\mathrm{CD} 4^{+}$and $\mathrm{CD} 8^{+} \mathrm{T}$ cells (Fig. 1B), based on their differential expression of CD28 and CD45RA (19). Eomes was expressed more strongly by all $\mathrm{CD} 8^{+}$compared to $\mathrm{CD} 4^{+}$naïve and memory $\mathrm{T}$ cell subsets. In both $\mathrm{CD} 4^{+}$ and especially $\mathrm{CD} 8^{+}$populations, $\mathrm{Tcm}$ displayed the highest Eomes expression (Fig. 1B and 1C). In $\mathrm{CD} 4^{+} \mathrm{T}$ cells, mean Eomes expression by $\mathrm{Tcm}(4.1 \%)$ was significantly higher than that by effector $\mathrm{T}$ cells (Teff; $1 \%$ ), but not naïve (Tn; $2.3 \%$ ) or effector memory $\mathrm{T}$ cells (Tem; $1.6 \%)$. In $\mathrm{CD} 8^{+} \mathrm{T}$ cells, mean Eomes expression by $\mathrm{Tcm}(47.3 \%)$ was significantly higher than for all other subsets,- Tem (29.4\%), Tn (23.5\%) and Teff (18.9\%) (Fig. 1C). We then evaluated Eomes versus CTLA4 expression by both $\mathrm{CD} 4^{+}$and $\mathrm{CD} 8^{+}$naïve and memory $\mathrm{T}$ cell subsets (Fig. 1D). In correlation with previous results, low percentages of Eomes ${ }^{\text {hi }}$ CTLA $44^{\text {lo }}$ and high percentages of Eomes ${ }^{\text {lo }}$ CTLA $4{ }^{\text {hi }}$ cells were detected in all $\mathrm{CD} 4^{+} \mathrm{T}$ cell subsets, compared to $\mathrm{CD} 8^{+} \mathrm{T}$ cells. $\mathrm{CD} 4^{+} \mathrm{Tcm}$ and $\mathrm{CD} 4^{+} \mathrm{Tem}$ showed higher frequencies of Eomes ${ }^{\mathrm{lo}} \mathrm{CTLA} 44^{\mathrm{hi}}$ cells. While $\mathrm{CD} 8^{+} \mathrm{T}$ cell subsets exhibited minimal percentages of Eomes ${ }^{\text {lo }} \mathrm{CTLA} 44^{\text {hi }}$ cells $(<4 \%), \mathrm{CD} 8^{+} \mathrm{Tcm}$ comprised the highest percentage of Eomes ${ }^{\text {lo }}$ CTLA $4{ }^{\text {hi }}$ cells.

\section{Eomes ${ }^{\text {lo }} \mathrm{CTLA} 4^{\text {hi }} \mathrm{CD}^{+}{ }^{+} \mathrm{T}$ Cells Include a Higher Proportion of Putative Regulatory Cells}

In humans and rodents, memory-like regulatory $\mathrm{CD} 8^{+} \mathrm{T}$ cells suppress both auto- and alloimmune responses $(20-22)$. $\mathrm{CD} 8^{+} \mathrm{CD} 122$ (IL-2R $\beta$ chain) ${ }^{+} \mathrm{PD} 1^{+} \mathrm{T}$ cells suppress $\mathrm{T}$ cell proliferation and inflammatory cytokine production (23), inhibit allograft rejection $(24,25)$ and mediate allograft acceptance (26). We evaluated CD122, CD45RA, CCR7, PD1, CD25 and Foxp3 expression by Eomes ${ }^{\text {lo }} \mathrm{CTLA} 44^{\text {hi }}$ versus Eomes ${ }^{\text {hi }} \mathrm{CTLA} 4{ }^{\text {lo }} \mathrm{CD} 8^{+} \mathrm{T}$ cells in naïve monkeys (Fig. 1E). The incidence of $\mathrm{CD} 122^{+}$cells was higher in the Eomes ${ }^{\text {hi }} \mathrm{CTLA} 4^{\text {lo }}$ compared to the Eomes ${ }^{\mathrm{lo}} \mathrm{CTLA} 44^{\text {hi }}$ population. Overall, the Eomes ${ }^{\mathrm{lo}} \mathrm{CTLA} 44^{\mathrm{hi}}$ population exhibited a more central memory phenotype, i.e. a significantly higher incidence of CCR7 and a lower incidence of CD45RA ${ }^{+}$cells than the Eomes ${ }^{\text {hi CTLA }} 4^{\text {lo }}$ population. CD25 expression was low on both populations, but higher on Eomes ${ }^{\mathrm{lo}} \mathrm{CTLA} 4 \mathrm{hi}$ cells. Furthermore, the Eomes ${ }^{\mathrm{lo}} \mathrm{CTLA} 4{ }^{\mathrm{hi}} \mathrm{CD} 8^{+}$population exhibited a higher incidence of Foxp $3^{+}$cells compared to Eomes ${ }^{\text {hi }} \mathrm{CTLA} 44^{\text {lo }} \mathrm{CD} 8^{+} \mathrm{T}$ cells. These findings suggest that low Eomes and high CTLA4 expression by rhesus $\mathrm{CD} 8^{+} \mathrm{T}$ cells may be associated with a subset of cells with a regulatory phenotype. 


\section{Reciprocal Relationship Between Eomes and CTLA4 Expression by Alloreactive T Cells}

The association between high CTLA4 and low Eomes expression relates to recent evidence (18) that co-inhibitory CTLA4 may selectively inhibit Eomes expression by rodent CD $8^{+} \mathrm{T}$ cells. We therefore hypothesized that an inverse correlation might exist between CTLA4 and Eomes expression by alloactivated rhesus $\mathrm{T}$ cells. All proliferating $\mathrm{CD} 4^{+} \mathrm{T}$ cells displayed low Eomes expression (Fig. 2A, left), whereas proliferating CD8 ${ }^{+} \mathrm{T}$ cells displayed two distinct populations, with either low or high Eomes expression (Fig. 2A, right). Furthermore, proliferation of $\mathrm{CD} 8^{+} \mathrm{T}$ cells with low Eomes expression was significantly greater than that of those with high Eomes expression (Fig. 2B, left). We also examined CTLA4 expression by proliferating $\mathrm{CD} 4^{+}$and $\mathrm{CD} 8^{+} \mathrm{T}$ cells. Proliferating $\mathrm{CD} 4^{+} \mathrm{T}$ cells $\left(\right.$ Eomes ${ }^{\mathrm{lo}}$ ) displayed higher levels of CTLA4 than proliferating Eomes ${ }^{\mathrm{lo}}$ and Eomes ${ }^{\text {hi }} \mathrm{CD} 8^{+} \mathrm{T}$ cells Interestingly, $\mathrm{CD} 8{ }^{+}$Eomes $^{\text {lo }} \mathrm{T}$ cells expressed significantly higher levels of CTLA4 than CD8 ${ }^{+}$Eomes $^{\text {hi }} \mathrm{T}$ cells (Fig. 2 A, right panel and Fig. 2B, right panel).

In addition, we evaluated expression of CTLA4 by non-proliferating CD4 ${ }^{+}$and CD8 ${ }^{+} \mathrm{T}$ cells in relation to that of Eomes. In non-proliferating $\mathrm{CD} 8^{+} \mathrm{T}$ cells, no significant differences were observed in CTLA4 expression by Eomes negative, lo or hi subsets. In non-proliferating $\mathrm{CD} 4^{+} \mathrm{T}$ cells, Eomes ${ }^{+}$cells showed slightly higher CTLA4 expression than Eomes $^{-}$cells (Supplementary Fig. 1). These data indicate that proliferation of alloreactive $\mathrm{CD}^{+} \mathrm{T}$ cells is associated with increased frequency of a subset of Eomes ${ }^{\mathrm{lo}} \mathrm{CTLA} 44^{\mathrm{hi}}$ cells.

\section{Alloreactive Eomes ${ }^{\text {lo }}$ CTLA4 ${ }^{\text {hi }}$ CD8 ${ }^{+}$T Cells Exhibit an Increased Incidence of Tcm}

As Eomes is critical for maintenance of Tcm, we next evaluated the memory phenotype of Eomes ${ }^{\text {lo }} \mathrm{CTLA} 44^{\mathrm{hi}}$ and Eomes ${ }^{\mathrm{hi}} \mathrm{CTLA} 44^{\mathrm{lo}} \mathrm{CD} 8^{+} \mathrm{T}$ cells following allostimulation. When cultured without stimulation, $\mathrm{CD} 8^{+} \mathrm{T}$ cells comprised a much higher proportion of Eomes ${ }^{\text {hi CTLA } 4}{ }^{\text {lo }}$ than Eomes ${ }^{\text {lo CTLA } 4}{ }^{\text {hi }}$ T cells (Fig. 3A, left). As in previous experiments, no significant changes were observed in the percentages of Eomes ${ }^{\text {hi }} \mathrm{CTLA} 4^{\mathrm{lo}}$ or Eomes ${ }^{\text {lo }} \mathrm{CTLA} 44^{\mathrm{lo}} \mathrm{T}$ cells following allostimulation, however, Eomes ${ }^{\mathrm{lo}} \mathrm{CTLA} 4 \mathrm{hi} \mathrm{T}$ cells increased significantly (Fig. 3A left and Fig. 3B left). Next, we examined naïve and memory T cell subsets among Eomes ${ }^{\mathrm{lo}} \mathrm{CTLA} 4{ }^{\mathrm{hi}} \mathrm{CD} 8^{+} \mathrm{T}$ cells following allostimulation (Fig. 3A, right). Compared with Eomes ${ }^{\text {hi }} \mathrm{CTLA} 44^{\mathrm{lo}}$ or the Eomes ${ }^{\mathrm{lo}} \mathrm{CTLA} 4^{\mathrm{lo}} \mathrm{T}$ cells, Tcm in the Eomes ${ }^{\text {lo }}{ }^{2}$ TLA $4{ }^{\text {hi }} \mathrm{CD}^{+} \mathrm{T}$ cell population were markedly enriched (Fig. 3B, right).

\section{CD28 CB with CTLA4Ig Reduces CTLA4 Expression by CD8 ${ }^{+} \mathrm{T}$ Cells After Allostimulation}

The co-inhibitory molecules CTLA4 and PD1 are considered markers of T cell exhaustion and regulation, and they are also expressed by activated $\mathrm{T}$ cells $(27,28)$. In our previous study (16), DCreg infusion in transplanted monkeys was associated with upregulation of CTLA4 and PD1 double positive donor-reactive Tmem. We tested the influence of CTLA4Ig on CTLA4 and PD1 expression in relation to Eomes expression by alloreactive $\mathrm{CD} 8^{+} \mathrm{T}$ cells following allostimulation in MLR. As seen in Fig. 4A, proliferation of CD8 ${ }^{+} \mathrm{T}$ cells was significantly reduced, as expected. In the absence of CTLA4Ig, mean CTLA4 expression by stimulated $\mathrm{CD} 8^{+} \mathrm{T}$ cells was upregulated 4-5-fold. Meanwhile, expression of PD1 was increased modestly, although not significantly. Reduced $\mathrm{CD} 8^{+} \mathrm{T}$ cell proliferation in the presence in CTLA4Ig was accompanied by a significant reduction in proliferating $\mathrm{CTLA}^{+}{ }^{+}$cells, in a CTLA4Ig concentration-dependent manner. Concurrently, the total 
percentage of CTLA $4^{+} \mathrm{CD} 8^{+} \mathrm{T}$ cells was also reduced significantly by CTLA4Ig. While proliferating $\mathrm{PD} 1^{+}$cells were also reduced by CTLA4Ig, no similar reduction was observed for total $\mathrm{PD} 1^{+}$cells (Figures 4A and 4B). Notably, we found no evidence that, under these conditions, anti-CTLA4 mAb used to stain CTLA4 bound to any residual cell-bound fusion protein with consequent 'artificial' reduction in CTLA4 staining (data not shown).

\section{CD28 CB with CTLA4Ig Does Not Affect Eomes Expression by CD8+ T Cells After Allostimulation}

As Eomes is critical for Tmem maintenance and differentiation, preservation of high Eomes expression associated with low CTLA4 expression by T cells, may play a role in the development CB-resistant Tmem. Having shown that CD28 CB reduces proliferating alloreactive $\mathrm{CD} 8{ }^{+} \mathrm{CTLA} 4^{+} \mathrm{T}$ cells (Figures $4 \mathrm{~A}$ and $4 \mathrm{~B}$ ), we next examined the influence of CTLA4Ig on Eomes expression by $\mathrm{CD} 8^{+} \mathrm{T}$ cells following allostimulation. Proliferation of Eomes ${ }^{\text {hi }}$ and Eomes ${ }^{l o}$ cells was increased following allostimulation and reduced in the presence of CTLA4Ig (Fig. 5A). However, the total percentage of Eomes ${ }^{+}$cells was not reduced by CTLA4Ig. In parallel, expression of Eomes by $\mathrm{CD} 8^{+} \mathrm{T}$ cells was increased significantly following allostimulation, but was not reduced by addition of CTLA4Ig at the start of MLR cultures. At the same time, however, CTLA4 expression was reduced significantly (Fig. 5A, lower left). In correlation, no marked changes in the incidence of Eomes ${ }^{\text {hi }} \mathrm{CTLA} 4{ }^{\text {lo }} \mathrm{CD} 8^{+} \mathrm{T}$ cells were observed after allostimulation in the absence or presence of CTLA4Ig (Fig. 5B, upper panel), while the incidence of Eomes ${ }^{\text {lo CTLA } 4{ }^{\text {hi }}}$ $\mathrm{CD} 8^{+} \mathrm{T}$ cells was reduced markedly by CTLA4Ig, in a concentration-dependent manner (Fig. 5B, lower panel).

To determine whether reduction in CTLA4 expression by alloreactive CD $8^{+} \mathrm{T}$ cells was unique to CD28 pathway blockade (by CTLA4Ig), we evaluated the influence of CD40/ CD40L blockade using anti-CD40 monoclonal antibody. Neither proliferation of $\mathrm{CD}^{+} \mathrm{T}$ cells nor the Eomes ${ }^{\text {lo }} \mathrm{CTLA} 4{ }^{\text {hi }} \mathrm{CD} 8{ }^{+} \mathrm{T}$ cell population was reduced in the presence of antiCD40 compared to CTLA4Ig (Supplementary Fig. 2).

\section{CTLA4 and PD1 Expression by CD8 ${ }^{+}$T Cells in Renal Allograft Recipients}

Recently we reported (16) prolonged graft survival in rhesus renal allograft recipients given CTLA4Ig and DCreg infusion compared with those that did not receive DCreg. This was associated with upregulation of co-inhibitory CTLA4 and PD1 by circulating CD8 ${ }^{+} \mathrm{Tmem}$ in response to ex-vivo donor but not $3^{\text {rd }}$ party stimulation. We hypothesized that a similar profile of donor-reactive $\mathrm{T}$ cells might be observed in the grafts of these DCreg recipients. Thus, we examined and quantified CTLA4 and PD1 expression by graft-infiltrating CD8 ${ }^{+} \mathrm{T}$ cells, one month post-transplant in two recipients from each of the control and DCreg groups. In the control group, graft-infiltrating $\mathrm{CD}^{+} \mathrm{T}$ cells showed minimal CTLA4 and PD1 expression, whereas strong expression of CTLA4 and PD1 by $\mathrm{CD}^{+} \mathrm{T}$ cells was observed in renal allografts of the DCreg group (Fig. 6). This was consistent with the corresponding upregulation of these inhibitory molecules on host $\mathrm{CD} 8^{+} \mathrm{T}$ cells following ex-vivo stimulation with donor $\mathrm{Ag}$ at the same time post-transplant (16). 


\section{DCreg Infusion Promotes Donor-Specific Eomes ${ }^{\text {lo }} \mathrm{CTLA}^{\mathrm{hi}} \mathrm{CD} 8^{+} \mathrm{Tcm}$ in CTLA4g-Treated Renal Allograft Recipients}

Next, we tested the in vivo relevance of differential Eomes and CTLA4 expression by alloreactive $\mathrm{CD}^{+}$Tmem in our transplant model (Fig. 7), in which DCreg infusion in CTLA4Ig-treated recipients is associated with selective attenuation of anti-donor Tmem responses (16). We examined the percentages (Fig. 7A and 7B, top panels) and absolute numbers (Fig. 7B; bottom panels) of peripheral blood alloreactive Eomes ${ }^{\text {lo }} \mathrm{CTLA} 4{ }^{\mathrm{hi}} \mathrm{CD}{ }^{+}$ Tcm following donor or $3^{\text {rd }}$ party stimulation, before and 1 month post-transplant, with or without DCreg infusion. In control monkeys (no DCreg infusion), donor-reactive Eomes ${ }^{\text {lo }}{ }^{\mathrm{CTLA}} 4{ }^{\text {hi }} \mathrm{CD} 8{ }^{+} \mathrm{Tcm}$ were reduced significantly post- compared to pre-transplant (Fig. 7B). By contrast, in graft recipients given DCreg infusion, the frequency of Eomes ${ }^{\text {lo }} \mathrm{CTLA} 4{ }^{\mathrm{hi}} \mathrm{CD} 8^{+} \mathrm{Tcm}$ following donor stimulation was increased modestly postcompared to pre-transplant (Fig. 7B, upper panels). More importantly, the mean percentage and absolute numbers of Eomes ${ }^{\mathrm{lo}} \mathrm{CTLA} 4{ }^{\mathrm{hi}} \mathrm{CD} 8^{+} \mathrm{Tcm}$ in the DCreg group were significantly higher than in the control group post-transplant. No similar differences were observed in response to $3^{\text {rd }}$ party stimulation.

\section{DISCUSSION}

Pre-existing alloreactive Tmem are considered a major barrier to induction of allograft tolerance $(1,29-31)$. As Tmem require less co-stimulation compared to naïve T cells (3234 ), alloreactive Tmem are thought to play a fundamental role in CB-resistant rejection (10, $35,36)$ and to preclude $\mathrm{CB}$-induced tolerance $(36,37)$. The T-box transcription factors Tbox expressed in $\mathrm{T}$ cells (T-bet and Eomes) are considered master regulators of CD8 ${ }^{+}$ effector Tmem differentiation and function $(13,14,38,39)$. Both T-bet and Eomes have cooperative and redundant roles in $\mathrm{CD} 8^{+} \mathrm{T}$ cell function, but they also have distinct roles in $\mathrm{CD}^{+}$Tmem development. Eomes plays a critical role in long-term survival of Ag-specific $\mathrm{Tcm}$ (15). In rodents, Eomes is upregulated in early Teff, where its expression increases as $\mathrm{T}$ cells progress from an effector to a memory phenotype $(15,40,41)$. Additionally, Eomes knockouts are deficient in long-term formation and homeostatic renewal of Tmem $(14,15$, $42)$.

The role of Eomes in the differentiation, regulation and maintenance of donor-specific Tmem in allograft recipients has hitherto not been examined. Furthermore, the expression of Eomes by Tn and Tmem in NHP has not previously been reported. We examined the expression of Eomes by alloreactive $\mathrm{CD} 4^{+}$and $\mathrm{CD} 8^{+} \mathrm{T}$ cells in normal monkeys and found that $\mathrm{CD} 8^{+} \mathrm{T}$ cells expressed significantly higher levels than $\mathrm{CD} 4^{+} \mathrm{T}$ cells. Similarly to humans (43), Tcm expressed the highest levels of Eomes compared to Tn, Tem and Teff. These observations suggest that Eomes may play a role in the development of donor-reactive $\mathrm{CD}^{+}$Tmem after transplantation.

It has been reported that CTLA4 may reduce Eomes expression by CD8 ${ }^{+} \mathrm{T}$ cells (18). In the current study, we evaluated Eomes and CTLA 4 expression by rhesus alloreactive CD8 ${ }^{+} \mathrm{T}$ cells. Following allostimulation, $\mathrm{CD} 8^{+} \mathrm{T}$ cells upregulated both CTLA4 and Eomes. Following allostimulation, all proliferating $\mathrm{CD} 4^{+} \mathrm{T}$ cells exhibited low Eomes but high CTLA4 expression. In contrast, proliferating $\mathrm{CD} 8^{+} \mathrm{T}$ cells comprised two distinct 
populations, one with high and one with low Eomes expression. Interestingly, CTLA4 expression by Eomes ${ }^{\text {hi }} \mathrm{CD} 8^{+} \mathrm{T}$ cells was lower than that by Eomes ${ }^{\mathrm{lo}} \mathrm{CD} 8^{+} \mathrm{T}$ cells, suggesting an inverse relationship between CTLA4 and Eomes expression. In correlation, we observed a significant increase in Eomes ${ }^{\mathrm{lo}} \mathrm{CTLA} 44^{\mathrm{hi}} \mathrm{CD} 8^{+} \mathrm{T}$ cells following allostimulation, compared to Eomes ${ }^{\text {hi }} \mathrm{CTLA} 44^{\mathrm{lo}}$ or Eomes ${ }^{\text {lo }} \mathrm{CTLA} 44^{\mathrm{lo}} \mathrm{T}$ cells. Furthermore, $70 \%$ of these Eomes ${ }^{\mathrm{lo}} \mathrm{CTLA} 4{ }^{\mathrm{hi}} \mathrm{CD} 8^{+} \mathrm{T}$ cells were $\mathrm{Tcm} . \mathrm{CD} 28 \mathrm{CB}$ with CTLA4Ig during allostimulation did not reduce Eomes expression on $\mathrm{CD} 8^{+} \mathrm{T}$ cells, despite efficient inhibition of $\mathrm{T}$ cell proliferation and significant reduction in CTLA4 expression. In the presence of CTLA4Ig, there was a reduction in the Eomes ${ }^{\text {lo }} \mathrm{CTLA} 44^{\mathrm{hi}}$ population, with minimal effect on Eomes ${ }^{\text {hi CTLA }} 4^{\text {lo }} \mathrm{T}$ cells. These observations indicate that blocking CD28 costimulation maintains alloreactive $\mathrm{T}$ cells with high Eomes levels, while reducing those with high CTLA4 expression.

Regulatory $\mathrm{CD}^{+} \mathrm{T}$ cells with a memory phenotype suppress both auto- and allo-immune responses (20-22). In rodents, $\mathrm{CD} 122^{+} \mathrm{PD} 1^{+}$regulatory $\mathrm{CD} 8^{+} \mathrm{T}$ cells suppress $\mathrm{T}$ cell responses in vitro and in vivo in an IL-10-dependent manner (23). Additionally, bystander $\mathrm{CD} 8^{+} \mathrm{Tcm}$ (and not Tem) prevent islet allograft rejection (24) and mediate lung allograft acceptance (26). Furthermore, naturally-occurring $\mathrm{CD} 8^{+} \mathrm{CD} 122^{+} \mathrm{T}$ cells appear more suppressive than $\mathrm{CD} 4{ }^{+} \mathrm{CD} 25^{+}$Treg (25) and are usually considered Ag-specific memory $\mathrm{T}$ cells with a central memory phenotype (44-46). In this study, we evaluated CD122, CD45RA, CCR7, PD1, CD25 and Foxp3 expression by Eomes ${ }^{\text {lo }}$ CTLA4 4 hi $C D 8^{+} \mathrm{T}$ cells in vitro and found that these cells expressed lower CD122 than Eomes ${ }^{\text {hi }} \mathrm{CTLA} 44^{\mathrm{lo}} \mathrm{CD} 8^{+} \mathrm{T}$ cells. In humans, $\mathrm{CD} 8^{+} \mathrm{CD} 122^{+}$Treg are not well-characterized. Moreover, while mouse $\mathrm{CD} 8{ }^{+} \mathrm{CD} 122^{+}$Treg are $\mathrm{CXCR}^{+}$, human $\mathrm{CD} 8{ }^{+} \mathrm{CXCR} 3^{+}$Treg are mostly $\mathrm{CD} 122^{-}(47)$.

The Eomes ${ }^{10} \mathrm{CTLA} 4{ }^{\mathrm{hi}}$ population exhibited a more central memory phenotype than the Eomes ${ }^{\text {hi }}$ CTLA $4{ }^{\text {lo }}$ population. Interestingly, despite low CD25 expression on both populations, Eomes ${ }^{\text {lo }} \mathrm{CTLA} 4{ }^{\text {hi }}$ cells displayed higher CD25 compared to Eomes ${ }^{\text {hi }}$ CTLA4 ${ }^{\text {lo }}$ $\mathrm{CD} 8^{+} \mathrm{T}$ cells. Of note, the Eomes ${ }^{\mathrm{lo}} \mathrm{CTLA} 44^{\mathrm{hi}} \mathrm{CD} 8^{+}$population also exhibited a higher frequency of Foxp 3 hi cells compared to Eomes ${ }^{\text {hi }} \mathrm{CTLA}^{+}{ }^{\text {lo }} \mathrm{CD} 8^{+} \mathrm{T}$ cells. Collectively, these findings suggest a more regulatory component within the Eomes ${ }^{\mathrm{lo}} \mathrm{CTLA} 4{ }^{\mathrm{hi}} \mathrm{CD} 8^{+} \mathrm{T}$ cell population. To our knowledge, regulatory $\mathrm{CD}^{+} \mathrm{T}$ cells have not been characterized in NHP and our future studies will address the regulatory function of these cells in our monkey transplant model.

Regulatory immune cell therapy offers considerable potential for promotion of transplant tolerance (48-53). DCreg can control Tmem responses (54-56) and are considered promising agents to promote clinical transplant tolerance $(49,57-61)$. We have reported (16) that a single infusion of donor-derived DCreg, one week before transplantation, combined with CTLA4Ig, prolongs renal allograft survival associated with enhanced coinhibitory CTLA4 and PD1 expression by circulating Tmem following stimulation with donor, but not third party alloAg. While PD1 and CTLA4 are considered markers of T cell exhaustion, they have distinct inhibitory effects on T cell activation (62). Tumors evade adaptive immune responses through upregulation of CTLA4 and PD1, while co-expression of CTLA4 and PD1 is associated with significant dysfunction of Ag-specific T cells (63). CTLA4 expression, with or without PD1, is associated with reduced $\mathrm{CD}^{+} \mathrm{T}$ cell 
proliferation and cytokine production. Furthermore, blocking of CTLA4 and PD1 interaction in vivo upregulates T-bet and Eomes in $\mathrm{CD}^{+} \mathrm{T}$ cells (63) required for in anti-tumor responses (64).

Our observations suggest that, when Tmem encounter donor Ag following infiltration of the graft, they may upregulate PD1 and CTLA4 that, in turn, may inhibit donor-reactive Tmem activation. To address this hypothesis, we examined PD-1 and CTLA4 expression by CD8 ${ }^{+}$ $\mathrm{T}$ cells in kidney allografts 28 days post-transplant. We found that graft-infiltrating $\mathrm{CD} 8^{+} \mathrm{T}$ cells displayed more CTLA4 and PD1 in the DCreg group than in the control group (no regulatory cell infusion). Since this enhanced expression of CTLA4 and PD1 by donorreactive Tmem may underlie improved graft survival in the DCreg group, we explored whether upregulation of these co-inhibitory molecules might be associated with regulation of donor-specific Tmem responses in the monkeys given DCreg infusion. Thus we ascertained the frequency of Eomes ${ }^{\text {lo }} \mathrm{CTLA} 44^{\mathrm{hi}} \mathrm{CD} 8^{+} \mathrm{Tcm}$ in allograft recipient monkeys in response to donor stimulation before and after transplant. In correlation with our in vitro observations, the frequency of Eomes ${ }^{\mathrm{lo}} \mathrm{CTLA} 44^{\mathrm{hi}} \mathrm{CD} 8^{+} \mathrm{Tcm}$ in response to donor stimulation was reduced significantly in the CTLA4Ig-treated monkeys (control group) posttransplant. By contrast, the frequency of Eomes ${ }^{10} \mathrm{CTLA} 4{ }^{\mathrm{hi}} \mathrm{CD} 8^{+} \mathrm{Tcm}$ was increased modestly after transplantation in the CTLA4Ig-treated monkeys given DCreg. More importantly, the mean percentages and absolute numbers of Eomes ${ }^{\mathrm{lo}} \mathrm{CTLA} 4{ }^{\mathrm{hi}} \mathrm{CD} 8{ }^{+} \mathrm{Tcm}$,- a phenotype that suggests low persistence and exhaustion, was significantly higher in the DCreg group than in the control group post-transplant.

Our observations provide further insight to the limitations of CD28 CB in organ transplantation. Significant reduction of the co-inhibitory receptor CTLA4 by alloreactive Tmem in the presence of CTLA4Ig in vitro and in CTLA4Ig-treated graft recipients posttransplant, together with no reduction in Eomes expression by donor-reactive Tmem, may be a key factor in CB resistance. While CTLA4Ig reduces effector T cell responses against donor Ag efficiently, this may be achieved at the expense of regulatory mechanisms that favor donor-specific Treg and attenuate donor-specific Tmem, resulting in increased rates of acute cellular rejection, as observed in belatacept-treated renal allograft recipients $(5,6)$.

These findings in rhesus monkeys identify CTLA4 as a marker of regulation of donorspecific, alloreactive Tmem, associated with improved transplant outcome. Upregulation of CTLA4 expression may play a role in attenuation of CB-resistant Tmem after transplantation. Whether pre-transplant DCreg infusion promotes the development of Eomes ${ }^{\text {lo }} \mathrm{CTLA} 44^{\text {hi }}$ donor-reactive $\mathrm{CD} 8^{+} \mathrm{T}$ cells, that are maintained after transplantation in response to the allograft, requires further investigation. The role of Eomes in development of alloreactive Tmem after transplantation has until now, not been ascertained. As Eomes plays a critical role in development and maintenance of Tcm (15), its reduced expression may attenuate donor-reactive Tcm after transplantation. Together with upregulation of CTLA4 by Tmem that we have shown in graft recipients given DCreg, this might further mitigate antidonor T cell responses. Furthermore, our observations suggest that DCreg infusion before renal transplantation may help preserve donor-specific Tmem regulation that is compromised with use of CD28 CB. 


\section{MATERIALS AND METHODS}

\section{Experimental Animals}

Indian male juvenile rhesus macaques (Macacca mulatta; 5-7 kg), obtained from the NIAID-sponsored colony (Yemasse, S.C.) were maintained in the NHP research facility of the Department of Laboratory Animal Resources at the University of Pittsburgh School of Medicine. All procedures were approved by the University of Pittsburgh Institutional Animal Care and Use Committee. Experiments were conducted according to the guidelines set forth in the National Institutes of Health Guide for the Care and Use of Laboratory Animals. Specific environment enrichment was provided.

\section{Renal Transplantation, DCreg Infusion and Immunosuppression}

Leukapheresis, generation of donor-derived DCreg and renal transplantation were performed as described $(16,65)$. Recipient pairs, i.e. control (no DCreg infusion) and experimental animals (DCreg infusion) received kidney grafts from the same MHC mis-matched donor. In the experimental group, DCreg $\left(3.5-10 \times 10^{6} / \mathrm{kg}\right)$ were infused intravenously, 7 days before transplantation. All recipients in the control and DCreg groups were given CTLA4Ig (abatacept; Bristol-Myers Squibb; Princeton, NJ)-based immunosuppression and maintenance rapamycin (16).

\section{Mixed Leukocyte Reactions (MLR)}

MLR were performed as described (16). In some MLRs, CTLA4Ig (1 $\mu \mathrm{g}$ or $100 \mu \mathrm{g} / \mathrm{ml})$ or primatized anti-CD40 antibody (Clone 2C10R4; $100 \mu \mathrm{g} / \mathrm{ml}$ ) was added at the start of culture. Samples were also obtained from normal monkeys or kidney allograft recipients as described previously (16). Thus, PBMC were isolated before and after transplantation (postoperative day [POD] 28) and co-cultured in MLR with either donor or third party stimulator cells. Data were acquired using an LSR II flow cytometer (Becton Dickinson, Franklin Lakes, NJ) and analyzed with FlowJo software (Tree Star, San Carlos, CA).

\section{Phenotypic Analysis of Alloreactive T Cells}

The following fluorochrome-labeled monoclonal antibodies (mAbs) were used for cell surface or intra-cellular flow staining of rhesus T cells: CD3 (clone: SP34-2) PerCP-Cy5.5, CD4 (clone: L200) APC-H7, CD28 (clone: CD28.2) APC-H7, CD45RA (clone: 5H9) PECy7 or FITC, CTLA4 (CD152; clone: BNI3) APC or VB450, CD122 (clone: Mik- 32 ) PE (all from BD Biosciences; San Jose, CA), CD8 (clone: RPA-T8) AF700, and CD95 (clone: DX2) PE-Cy7, Foxp3 (clone: 206D) AF488, CD25 (clone: BC96) AF700 (all from Biolegend; San Diego, CA), PD-1 (CD279; clone: eBioJ105) PE and Eomesodermin (clone: WD1928) eFluor 660, CCR7 (clone: 3D12) PE (all from eBioscience; San Diego, CA). Data were acquired and analyzed as described above. For renal allograft recipients' samples, percentages obtained for specific populations were used to determine absolute numbers based on WBC in the peripheral blood. 


\section{Immunofluorescence Staining of Kidney Allografts}

Tissues were collected from graft recipients in the control group on the day of euthanasia following clinical evidence of rejection and from those in the DCreg group on POD 28 by open biopsy of the kidney graft. Tissues were embedded in O.C.T. (Miles), snap-frozen and stored at $-80^{\circ} \mathrm{C}$. Cryostat sections $(8-10 \mu \mathrm{m})$ were mounted on slides pre-coated with Vectabond (Vector) then fixed in $96 \%$ ethanol and allowed to dry. Sections were blocked successively with 5\% goat serum and an avidin/biotin blocking kit (Vector). Next, sections were incubated with anti-human CD8 Ab (clone LT8, Abcam, 1:100, overnight, $10^{\circ} \mathrm{C}$ ), followed by Alexa Fluor 555-goat anti-mouse IgG (Molecular Probes, 1:100, 1h, RT). The slides were then blocked with mouse irrelevant IgG1 (BD Biosystems, 1:100, 1h, RT) and incubated successively with (i) biotin anti-human CTLA4 (CD152) (clone BNI3, BD Biosystems, 1:100, 1h, RT), (ii) DyLight 488-streptavidin (Jackson ImmunoResearch Laboratories, 1:400, $30 \mathrm{~min}, \mathrm{RT}$ ), and (iii) Alexa Fluor 647-conjugated anti-human PD1 (CD279) Ab (clone EH12.2H7, Biolegend, 1:100, 1h, RT). Cell nuclei were stained with DAPI (Molecular Probes).

\section{Statistical Analyses}

The significance of differences between groups was determined using Kruskal-Wallis oneway analysis of variance or Mann-Whitney U test, as appropriate. Significance was defined as $\mathrm{p}<0.05$.

\section{Supplementary Material}

Refer to Web version on PubMed Central for supplementary material.

\section{Acknowledgments}

Funding: This study was supported by National Institutes of Health (NIH) grant U01 AI51698, part of the NIH NHP Transplantation Tolerance Study group and sponsored by the NIAID and NIDDK.

\section{Abbreviations}

$\begin{array}{ll}\text { CB } & \begin{array}{l}\text { costimulation blockade } \\ \text { CFSE }\end{array} \\ \text { CTLA4 (-Ig) } & \begin{array}{l}\text { cytotoxic T lymphocyte antigen 4 (-immunoglobulin) } \\ \text { DC }\end{array} \\ \text { DCreg } & \text { rendritic cells } \\ \text { Eomes } & \text { eomesodermin } \\ \text { PD1 } & \text { programed death 1 } \\ \text { Tcm } & \text { central memory T cells } \\ \text { Teff } & \text { effector T cells } \\ \text { Tem } & \text { effector memory T cells }\end{array}$


$\begin{array}{ll}\text { Tmem } & \text { T memory cells } \\ \text { Tn } & \text { naïve T cells }\end{array}$

\section{References}

1. Valujskikh A, Li XC. Frontiers in nephrology: T cell memory as a barrier to transplant tolerance. J Am Soc Nephrol. 2007; 18(8):2252. [PubMed: 17634436]

2. Kean LS, Adams AB, Strobert E, et al. Induction of chimerism in rhesus macaques through stem cell transplant and costimulation blockade-based immunosuppression. Am J Transplant. 2007; 7(2): 320. [PubMed: 17241112]

3. Larsen CP, Page A, Linzie KH, et al. An MHC-defined primate model reveals significant rejection of bone marrow after mixed chimerism induction despite full MHC matching. Am J Transplant. 2010; 10(11):2396. [PubMed: 20849552]

4. Page A, Srinivasan S, Singh K, et al. CD40 blockade combines with CTLA4Ig and sirolimus to produce mixed chimerism in an MHC-defined rhesus macaque transplant model. Am J Transplant. 2012; 12(1):115. [PubMed: 21929643]

5. Vincenti F, Charpentier B, Vanrenterghem Y, et al. A phase III study of belatacept-based immunosuppression regimens versus cyclosporine in renal transplant recipients (BENEFIT study). Am J Transplant. 2010; 10(3):535. [PubMed: 20415897]

6. Pestana JO, Grinyo JM, Vanrenterghem Y, et al. Three-year outcomes from BENEFIT-EXT: a phase III study of belatacept versus cyclosporine in recipients of extended criteria donor kidneys. Am J Transplant. 2012; 12(3):630. [PubMed: 22300431]

7. Charbonnier LM, Vokaer B, Lemaitre PH, Field KA, Leo O, Le Moine A. CTLA4-Ig restores rejection of MHC class-II mismatched allografts by disabling IL-2-expanded regulatory T cells. Am J Transplant. 2012; 12(9):2313. [PubMed: 22759373]

8. Riella LV, Liu T, Yang J, et al. Deleterious effect of CTLA4-Ig on a Treg-dependent transplant model. Am J Transplant. 2012; 12(4):846. [PubMed: 22300534]

9. Ferrari-Lacraz S, Zheng XX, Kim YS, et al. An antagonist IL-15/Fc protein prevents costimulation blockade-resistant rejection. J Immunol. 2001; 167(6):3478. [PubMed: 11544341]

10. Trambley J, Bingaman AW, Lin A, et al. Asialo GM1(+) CD8(+) T cells play a critical role in costimulation blockade-resistant allograft rejection. J Clin Invest. 1999; 104(12):1715. [PubMed: 10606625]

11. Ferrari-Lacraz S, Zheng XX, Fueyo AS, Maslinski W, Moll T, Strom TB. CD8(+) T cells resistant to costimulatory blockade are controlled by an antagonist interleukin-15/Fc protein. Transplantation. 2006; 82(11):1510. [PubMed: 17164724]

12. Kitchens WH, Haridas D, Wagener ME, et al. Integrin antagonists prevent costimulatory blockaderesistant transplant rejection by CD8(+) memory T cells. Am J Transplant. 2012; 12(1):69. [PubMed: 21942986]

13. Pearce EL, Mullen AC, Martins GA, et al. Control of effector CD8+ T cell function by the transcription factor Eomesodermin. Science. 2003; 302(5647):1041. [PubMed: 14605368]

14. Intlekofer AM, Takemoto N, Wherry EJ, et al. Effector and memory CD8+ T cell fate coupled by T-bet and eomesodermin. Nat Immunol. 2005; 6(12):1236. [PubMed: 16273099]

15. Banerjee A, Gordon SM, Intlekofer AM, et al. Cutting edge: The transcription factor eomesodermin enables CD8+ T cells to compete for the memory cell niche. J Immunol. 2010; 185(9):4988. [PubMed: 20935204]

16. Ezzelarab MB, Zahorchak AF, Lu L, et al. Regulatory dendritic cell infusion prolongs kidney allograft survival in nonhuman primates. Am J Transplant. 2013; 13(8):1989. [PubMed: 23758811]

17. Azimzadeh AM, Bromberg JS. Transplantation: Negative vaccination to modulate transplant immunity. Nat Rev Nephrol. 2013; 9(10):557. [PubMed: 23979489] 
18. Hegel JK, Knieke K, Kolar P, Reiner SL, Brunner-Weinzierl MC. CD152 (CTLA-4) regulates effector functions of CD8+ T lymphocytes by repressing Eomesodermin. Eur J Immunol. 2009; 39(3):883. [PubMed: 19224637]

19. Pitcher CJ, Hagen SI, Walker JM, et al. Development and homeostasis of T cell memory in rhesus macaque. J Immunol. 2002; 168(1):29. [PubMed: 11751943]

20. Smith TR, Kumar V. Revival of CD8+ Treg-mediated suppression. Trends Immunol. 2008; 29(7): 337. [PubMed: 18514574]

21. Guillonneau C, Picarda E, Anegon I. CD8+ regulatory T cells in solid organ transplantation. Curr Opin Organ Transplant. 2010; 15(6):751. [PubMed: 20881498]

22. Li S, Xie Q, Zeng Y, et al. A naturally occurring CD8(+)CD122(+) T-cell subset as a memory-like Treg family. Cell Mol Immunol. 2014; 11(4):326. [PubMed: 24793406]

23. Dai H, Wan N, Zhang S, Moore Y, Wan F, Dai Z. Cutting edge: programmed death-1 defines CD8+CD122+ T cells as regulatory versus memory T cells. J Immunol. 2010; 185(2):803. [PubMed: 20548035]

24. Wan N, Dai H, Wang T, Moore Y, Zheng XX, Dai Z. Bystander central memory but not effector memory CD8+ T cells suppress allograft rejection. J Immunol. 2008; 180(1):113. [PubMed: 18097010]

25. Dai Z, Zhang S, Xie Q, et al. Natural CD8+CD122+ T cells are more potent in suppression of allograft rejection than CD4+CD25+ regulatory T cells. Am J Transplant. 2014; 14(1):39. [PubMed: 24219162]

26. Krupnick AS, Lin X, Li W, et al. Central memory CD8+ T lymphocytes mediate lung allograft acceptance. J Clin Invest. 2014; 124(3):1130. [PubMed: 24569377]

27. Vibhakar R, Juan G, Traganos F, Darzynkiewicz Z, Finger LR. Activation-induced expression of human programmed death-1 gene in T-lymphocytes. Exp Cell Res. 1997; 232(1):25. [PubMed: 9141617]

28. Linsley PS, Bradshaw J, Greene J, Peach R, Bennett KL, Mittler RS. Intracellular trafficking of CTLA-4 and focal localization towards sites of TCR engagement. Immunity. 1996; 4(6):535. [PubMed: 8673700]

29. Ford ML, Larsen CP. Overcoming the memory barrier in tolerance induction: molecular mimicry and functional heterogeneity among pathogen-specific T-cell populations. Curr Opin Organ Transplant. 2010; 15(4):405. [PubMed: 20616729]

30. Valujskikh A. The challenge of inhibiting alloreactive T-cell memory. Am J Transplant. 2006; 6(4):647. [PubMed: 16539619]

31. Lakkis FG, Sayegh MH. Memory T cells: a hurdle to immunologic tolerance. J Am Soc Nephrol. 2003; 14(9):2402. [PubMed: 12937320]

32. Jameson SC, Masopust D. Diversity in T cell memory: an embarrassment of riches. Immunity. 2009; 31(6):859. [PubMed: 20064446]

33. Valujskikh A, Pantenburg B, Heeger PS. Primed allospecific T cells prevent the effects of costimulatory blockade on prolonged cardiac allograft survival in mice. Am J Transplant. 2002; 2(6):501. [PubMed: 12118893]

34. Croft M, Bradley LM, Swain SL. Naive versus memory CD4 T cell response to antigen. Memory cells are less dependent on accessory cell costimulation and can respond to many antigenpresenting cell types including resting B cells. J Immunol. 1994; 152(6):2675. [PubMed: 7908301]

35. Zhai Y, Meng L, Gao F, Busuttil RW, Kupiec-Weglinski JW. Allograft rejection by primed/ memory CD8+ T cells is CD154 blockade resistant: therapeutic implications for sensitized transplant recipients. J Immunol. 2002; 169(8):4667. [PubMed: 12370407]

36. Farber DL. Identification and targeting of costimulation-resistant $\mathrm{T}$ cells in renal transplantation. Am J Transplant. 2011; 11(1):8. [PubMed: 21199342]

37. Ford ML, Kirk AD, Larsen CP. Donor-reactive T-cell stimulation history and precursor frequency: barriers to tolerance induction. Transplantation. 2009; 87(9 Suppl):S69. [PubMed: 19424013]

38. Angelosanto JM, Wherry EJ. Transcription factor regulation of CD8+ T-cell memory and exhaustion. Immunol Rev. 2010; 236:167. [PubMed: 20636816] 
39. Li G, Yang Q, Zhu Y, et al. T-Bet and Eomes Regulate the Balance between the Effector/Central Memory T Cells versus Memory Stem Like T Cells. PLoS One. 2013; 8(6):e67401. [PubMed: 23826287]

40. Pipkin ME, Sacks JA, Cruz-Guilloty F, Lichtenheld MG, Bevan MJ, Rao A. Interleukin-2 and inflammation induce distinct transcriptional programs that promote the differentiation of effector cytolytic T cells. Immunity. 2010; 32(1):79. [PubMed: 20096607]

41. Joshi NS, Cui W, Dominguez CX, Chen JH, Hand TW, Kaech SM. Increased numbers of preexisting memory CD8 T cells and decreased T-bet expression can restrain terminal differentiation of secondary effector and memory CD8 T cells. J Immunol. 2011; 187(8):4068. [PubMed: 21930973]

42. Kaech SM, Hemby S, Kersh E, Ahmed R. Molecular and functional profiling of memory CD8 T cell differentiation. Cell. 2002; 111(6):837. [PubMed: 12526810]

43. McLane LM, Banerjee PP, Cosma GL, et al. Differential localization of T-bet and Eomes in CD8 T cell memory populations. J Immunol. 2013; 190(7):3207. [PubMed: 23455505]

44. Zhang X, Sun S, Hwang I, Tough DF, Sprent J. Potent and selective stimulation of memoryphenotype CD8+ T cells in vivo by IL-15. Immunity. 1998; 8(5):591. [PubMed: 9620680]

45. Ku CC, Murakami M, Sakamoto A, Kappler J, Marrack P. Control of homeostasis of CD8+ memory T cells by opposing cytokines. Science. 2000; 288(5466):675. [PubMed: 10784451]

46. Judge AD, Zhang X, Fujii H, Surh CD, Sprent J. Interleukin 15 controls both proliferation and survival of a subset of memory-phenotype CD8(+) T cells. J Exp Med. 2002; 196(7):935. [PubMed: 12370255]

47. Shi Z, Okuno Y, Rifa'i M, et al. Human CD8+CXCR3+ T cells have the same function as murine CD8+CD122+ Treg. Eur J Immunol. 2009; 39(8):2106. [PubMed: 19609979]

48. Bluestone JA, Thomson AW, Shevach EM, Weiner HL. What does the future hold for cell-based tolerogenic therapy? Nat Rev Immunol. 2007; 7(8):650. [PubMed: 17653127]

49. Morelli AE, Thomson AW. Tolerogenic dendritic cells and the quest for transplant tolerance. Nat Rev Immunol. 2007; 7(8):610. [PubMed: 17627284]

50. Lombardi G, Sagoo P, Scotta C, et al. Cell therapy to promote transplantation tolerance: a winning strategy? Immunotherapy. 2011; 3(4 Suppl):28. [PubMed: 21524166]

51. Wood KJ, Bushell A, Hester J. Regulatory immune cells in transplantation. Nat Rev Immunol. 2012; 12(6):417. [PubMed: 22627860]

52. Geissler EK, Hutchinson JA. Cell therapy as a strategy to minimize maintenance immunosuppression in solid organ transplant recipients. Curr Opin Organ Transplant. 2013; 18(4): 408. [PubMed: 23838645]

53. Hutchinson JA, Ahrens N, Riquelme P, et al. Clinical management of patients receiving cell-based immunoregulatory therapy. Transfusion. 2014

54. Nasreen M, Waldie TM, Dixon CM, Steptoe RJ. Steady-state antigen-expressing dendritic cells terminate CD4+ memory T-cell responses. Eur J Immunol. 2010; 40(7):2016. [PubMed: 20405475]

55. Anderson AE, Sayers BL, Haniffa MA, et al. Differential regulation of naive and memory CD4+ T cells by alternatively activated dendritic cells. J Leukoc Biol. 2008; 84(1):124. [PubMed: 18430785]

56. Kenna TJ, Waldie T, McNally A, et al. Targeting antigen to diverse APCs inactivates memory CD8+ T cells without eliciting tissue-destructive effector function. J Immunol. 2010; 184(2):598. [PubMed: 19995901]

57. van Kooten C, Lombardi G, Gelderman KA, et al. Dendritic cells as a tool to induce transplantation tolerance: obstacles and opportunities. Transplantation. 2011; 91(1):2. [PubMed: 21452405]

58. Ezzelarab M, Thomson AW. Tolerogenic dendritic cells and their role in transplantation. Semin Immunol. 2011; 23(4):252. [PubMed: 21741270]

59. Riquelme P, Geissler EK, Hutchinson JA. Alternative approaches to myeloid suppressor cell therapy in transplantation: comparing regulatory macrophages to tolerogenic DCs and MDSCs. Transplant Res. 2012; 1(1):17. [PubMed: 23369628] 
60. Beriou G, Moreau A, Cuturi MC. Tolerogenic dendritic cells: applications for solid organ transplantation. Curr Opin Organ Transplant. 2012; 17(1):42. [PubMed: 22227722]

61. Vassalli G. Dendritic cell-based approaches for therapeutic immune regulation in solid-organ transplantation. J Transplant. 2013; 2013:761429. [PubMed: 24307940]

62. Kaufmann DE, Walker BD. PD-1 and CTLA-4 inhibitory cosignaling pathways in HIV infection and the potential for therapeutic intervention. J Immunol. 2009; 182(10):5891. [PubMed: 19414738]

63. Duraiswamy J, Kaluza KM, Freeman GJ, Coukos G. Dual blockade of PD-1 and CTLA-4 combined with tumor vaccine effectively restores T-cell rejection function in tumors. Cancer Res. 2013; 73(12):3591. [PubMed: 23633484]

64. Zhu Y, Ju S, Chen E, et al. T-bet and eomesodermin are required for T cell-mediated antitumor immune responses. J Immunol. 2010; 185(6):3174. [PubMed: 20713880]

65. Zahorchak AF, Kean LS, Tokita D, et al. Infusion of stably immature monocyte-derived dendritic cells plus CTLA4Ig modulates alloimmune reactivity in rhesus macaques. Transplantation. 2007; 84(2):196. [PubMed: 17667811] 
Figure $1 \mathrm{~A}$
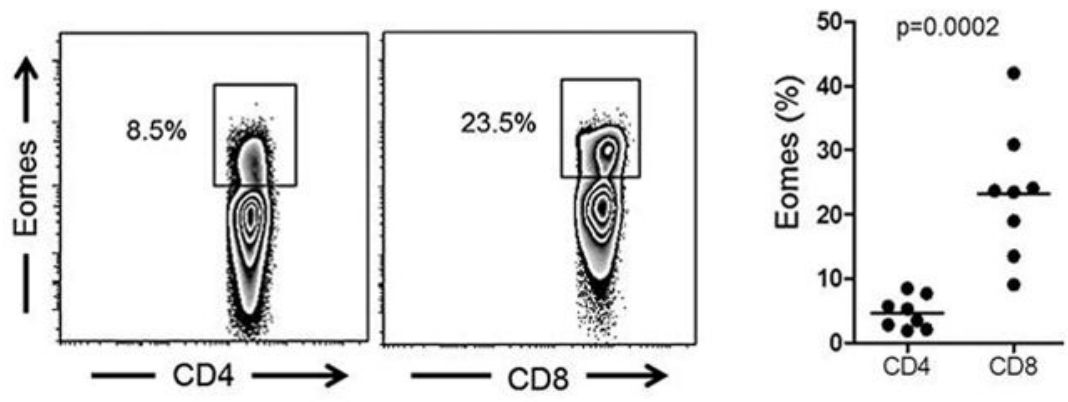

Figure 1B

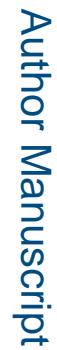
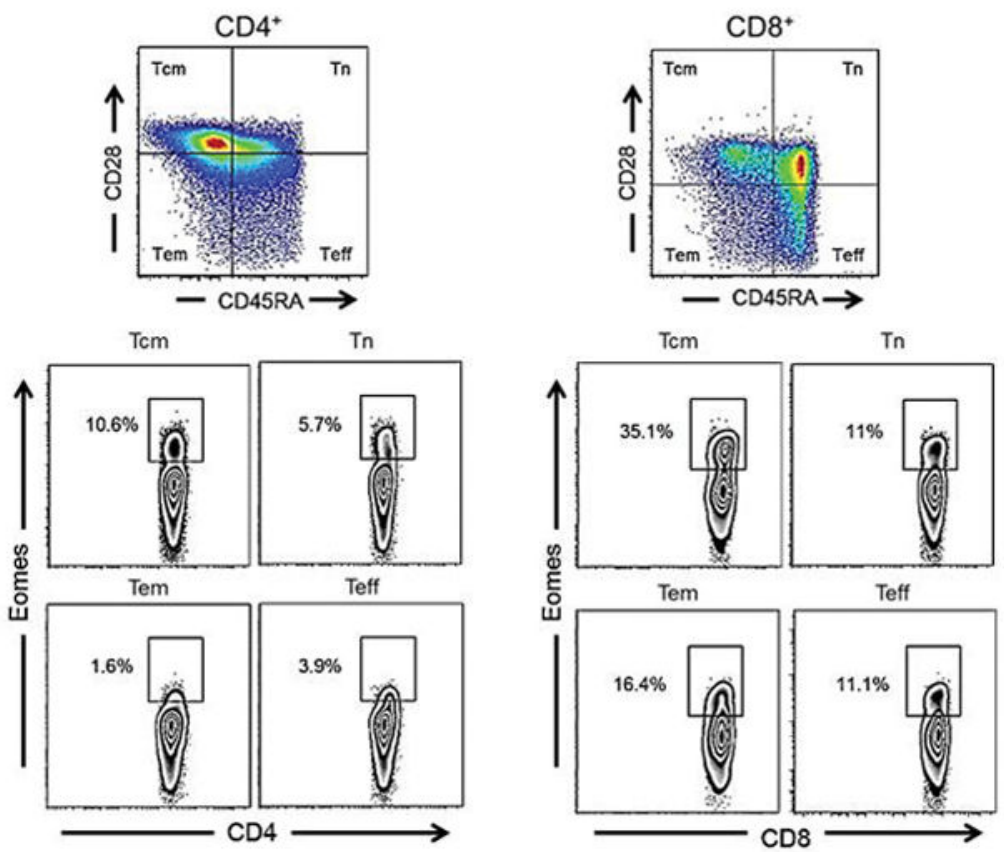

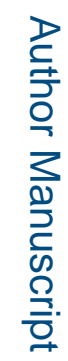


Figure 1C

$\mathrm{CD}^{+}$

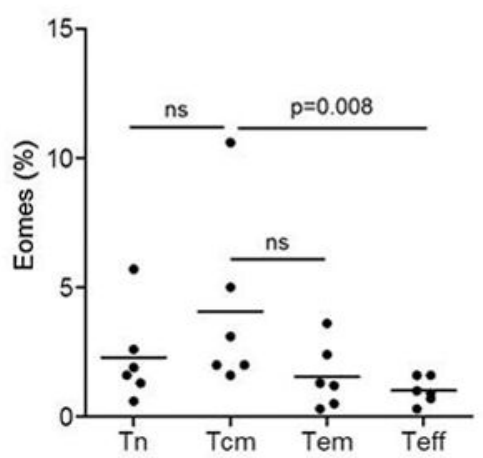

Figure 1D

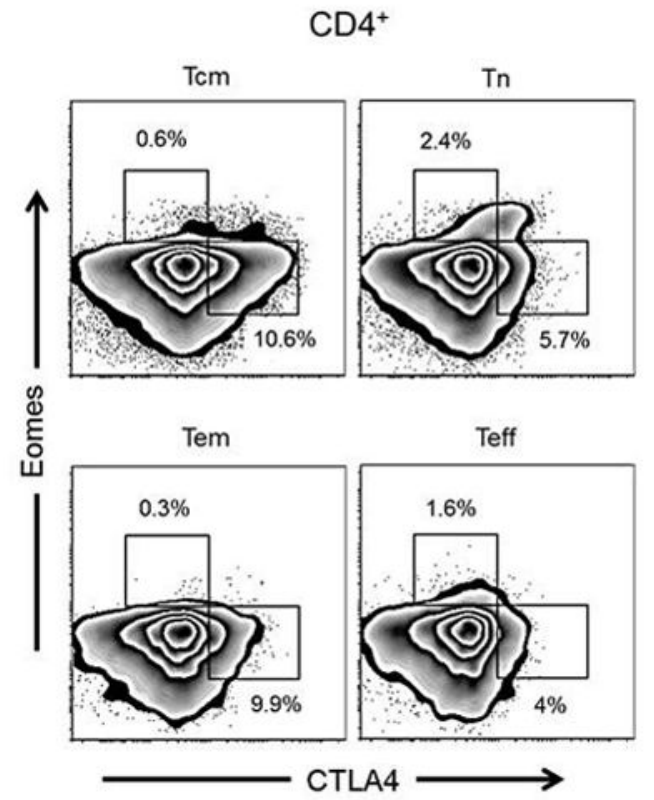

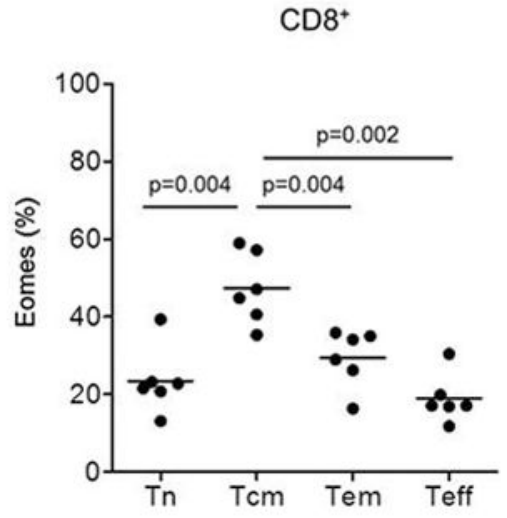

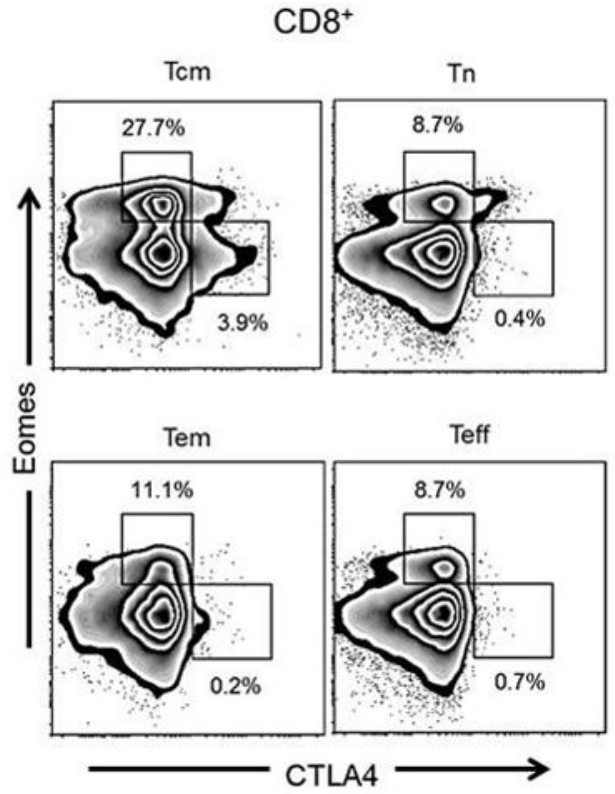

Transplantation. Author manuscript; available in PMC 2017 January 01. 
Figure 1E
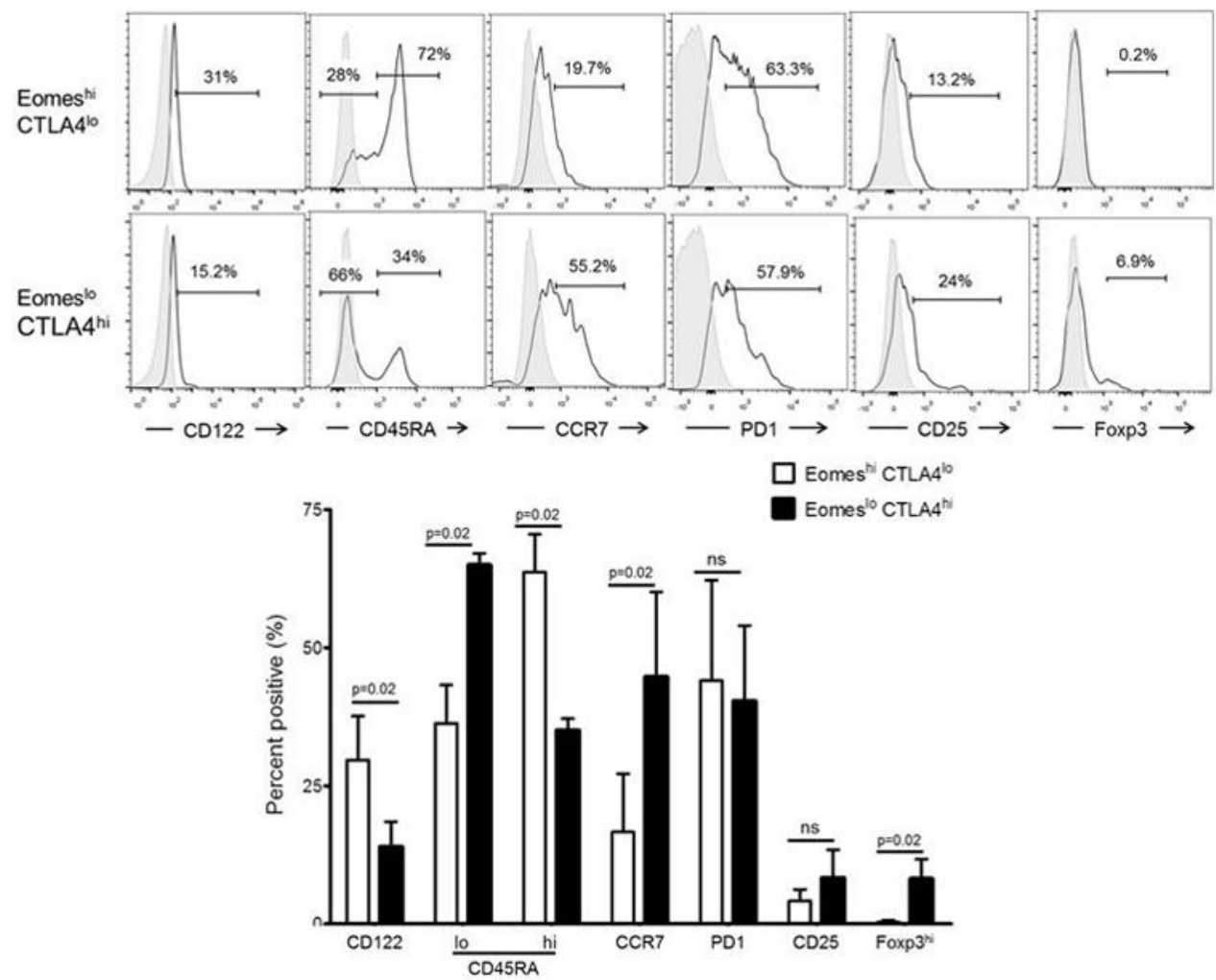

FIGURE 1.

Expression of Eomes and CTLA4 by normal rhesus monkey naïve and memory $\mathrm{CD}^{+}$and $\mathrm{CD}^{+} \mathrm{T}$ cells. (A) Left, expression of Eomes by total $\mathrm{CD} 4^{+}$and $\mathrm{CD} 8^{+}$peripheral blood $\mathrm{T}$ cells in a representative normal rhesus monkey determined by flow cytometry; right, individual and mean values for 8 normal monkeys. (B) Eomes expression by $\mathrm{CD} 4^{+}$and $\mathrm{CD} 8^{+}$naive and memory $\mathrm{T}$ cell subsets, determined by differential CD45RA and CD28 expression: central memory $\mathrm{T}$ cells $\left(\mathrm{Tcm}\right.$; $\left.\mathrm{CD} 45 \mathrm{RA}^{-} \mathrm{CD} 28^{+}\right)$, naïve $\mathrm{T}$ cells ( $\mathrm{Tn}$; CD45RA ${ }^{+} \mathrm{CD} 28^{+}$), effector memory T cells (Tem; CD45RA ${ }^{-} \mathrm{CD} 28^{-}$) and effector T cells (Teff; CD45RA ${ }^{+} \mathrm{CD} 28^{-}$). (C) Individual and mean incidences of Eomes ${ }^{+} \mathrm{CD} 4^{+}$and $\mathrm{CD} 8^{+} \mathrm{T}$ naïve and memory cell subtypes ( $n=6$ normal monkeys). (D) Eomes versus CTLA4 expression by $\mathrm{CD}^{+}$and $\mathrm{CD} 8^{+}$naive and memory $\mathrm{T}$ cell subsets in naïve monkeys (data representative of $\mathrm{n}=4$ monkeys). (E) CD122 (IL-2R $\beta$ ), CD45RA, CCR7, PD1, CD25 and Foxp3 expression by Eomes ${ }^{\text {lo }}$ CTLA $4{ }^{\text {hi }}$ versus Eomes ${ }^{\text {hi }}$ CTLA $4{ }^{\text {lo }} \mathrm{CD} 8^{+} \mathrm{T}$ cells in naïve monkeys. Representative data (above) and means $+1 \mathrm{SD}$ for $\mathrm{n}=4$ monkeys (below) are shown; ns = not significant. 
Figure 2A
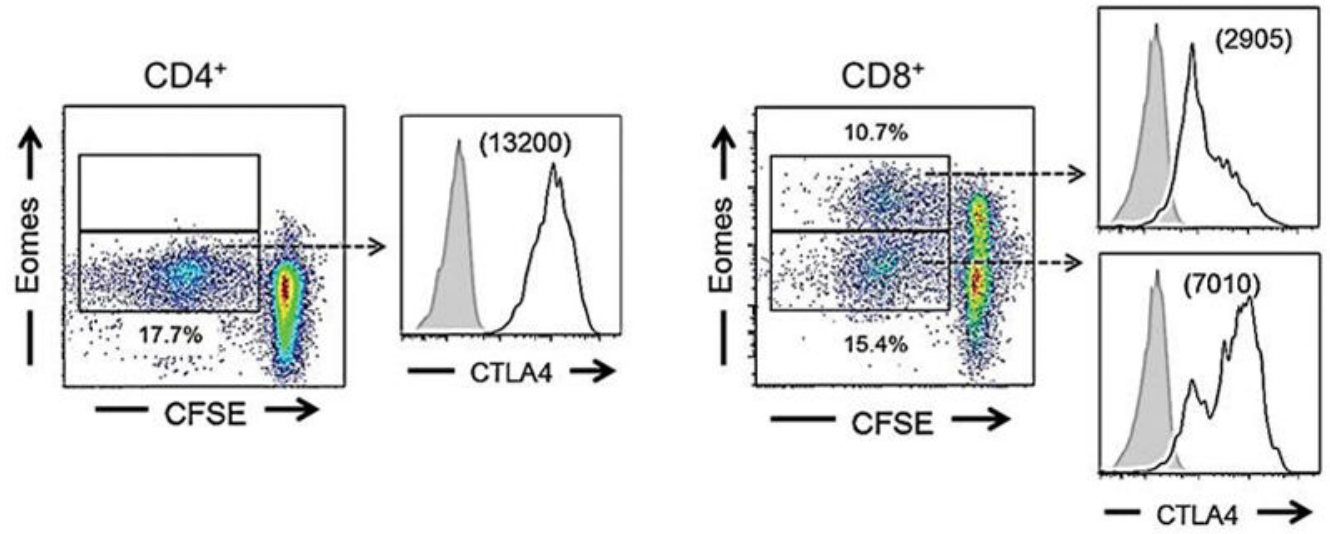

Figure 2B
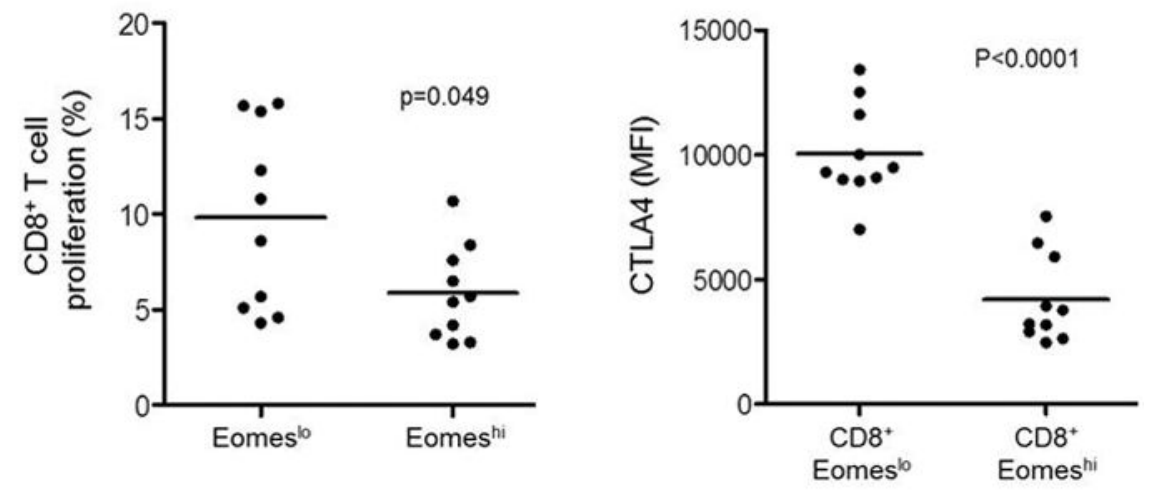

FIGURE 2.

Inverse correlation between Eomes and CTLA4 expression by alloreactive CD4 ${ }^{+}$and CD8 ${ }^{+}$ $\mathrm{T}$ cells in normal monkeys. Two distinct populations of Eomes ${ }^{\text {hi }}$ and Eomes ${ }^{\text {lo }}$ proliferating $\mathrm{CD}^{+} \mathrm{T}$ cells are observed following allostimulation of normal monkey $\mathrm{T}$ cells. (A) Proliferation of Eomes ${ }^{\mathrm{hi}}$ and Eomes ${ }^{\mathrm{lo}} \mathrm{CD} 4^{+}$and $\mathrm{CD} 8^{+} \mathrm{T}$ cells following allostimulation in CFSE-MLR. Histograms show CTLA4 expression by proliferating cells (values in parentheses indicate MFI). Grey histograms indicate isotype controls. (B) Left, proliferation of Eomes ${ }^{\text {hi }}$ compared with Eomes ${ }^{\text {lo }} \mathrm{CD} 8^{+} \mathrm{T}$ cells; right, CTLA4 expression (MFI) by proliferating Eomes ${ }^{\mathrm{lo}}$ and Eomes ${ }^{\text {hi }} \mathrm{CD} 8^{+} \mathrm{T}$ cells. Responder PBMC were co-cultured with allogeneic T cell-depleted PBMC for 5 days in CFSE-MLR. Proliferation of Eomeshi and Eomes $^{10} \mathrm{~T}$ cell populations were determined after gating on $\mathrm{CD} 4^{+}$or $\mathrm{CD} 8^{+} \mathrm{T}$ cells $(\mathrm{n}=10$ normal monkeys). 
Figure $3 \mathrm{~A}$

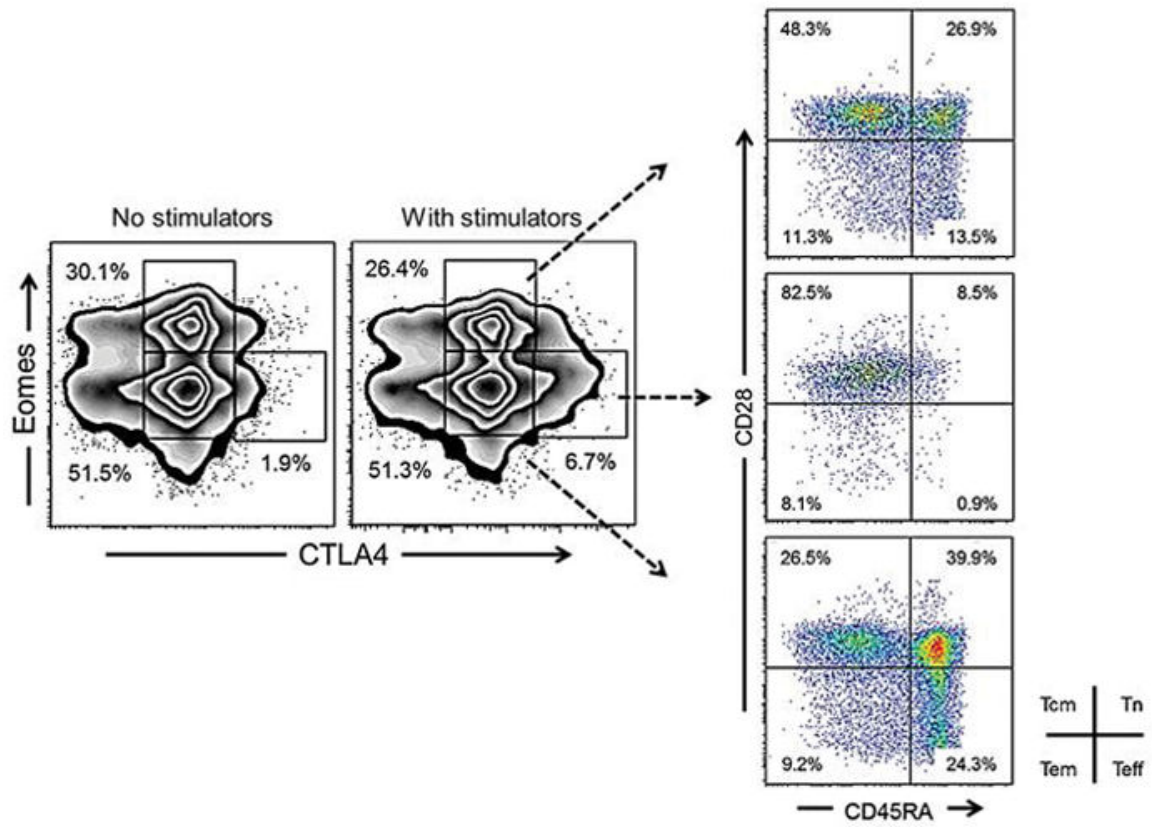

Figure 3B
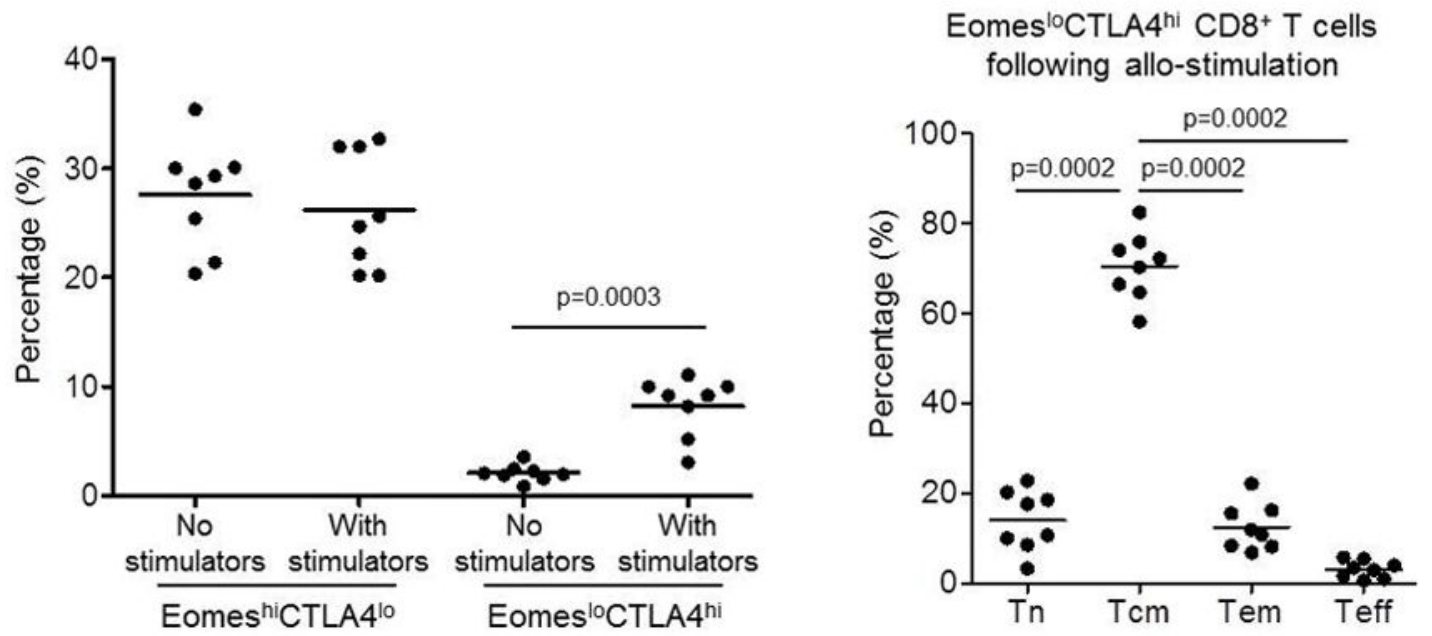

FIGURE 3.

Increased frequency of central memory $\mathrm{T}$ cells $(\mathrm{Tcm})$ in the Eomes ${ }^{\mathrm{lo}} \mathrm{CTLA} 44^{\mathrm{hi}} \mathrm{CD} 8^{+} \mathrm{T}$ cell population following allostimulation. (A) Frequencies of Eomes ${ }^{\text {hi }}$ CTLA ${ }^{\text {lo }}$ and Eomes ${ }^{\mathrm{lo}} \mathrm{CTLA} 4{ }^{\mathrm{hi}} \mathrm{CD} 8{ }^{+} \mathrm{T}$ cell subpopulations in MLR. Data are from a representative experiment. (B) left, combined data from 8 allogeneic monkey stimulator-responder combinations; right, frequencies of naïve and memory $\mathrm{T}$ cell subsets in the 
Eomes ${ }^{\text {lo }} \mathrm{CTLA} 44^{\mathrm{hi}} \mathrm{CD} 8{ }^{+} \mathrm{T}$ subpopulation after allo-stimulation. The combined data are from 8 different allogeneic monkey responder and stimulator pairs. 
Figure 4A

No stimulators

CD8
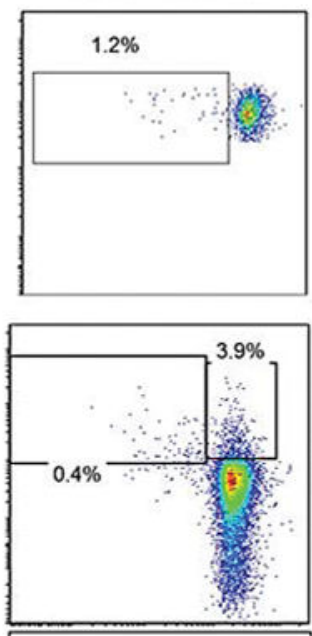

PD1

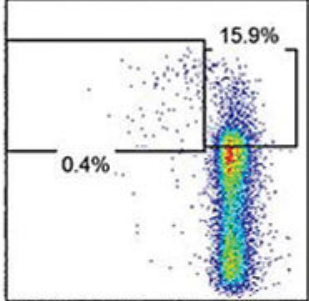

CTLA4<smiles>[PbH]</smiles>

No CTLA4Ig
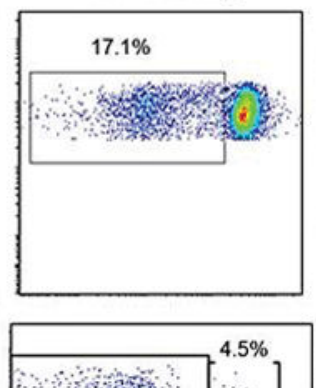

Figure 4B
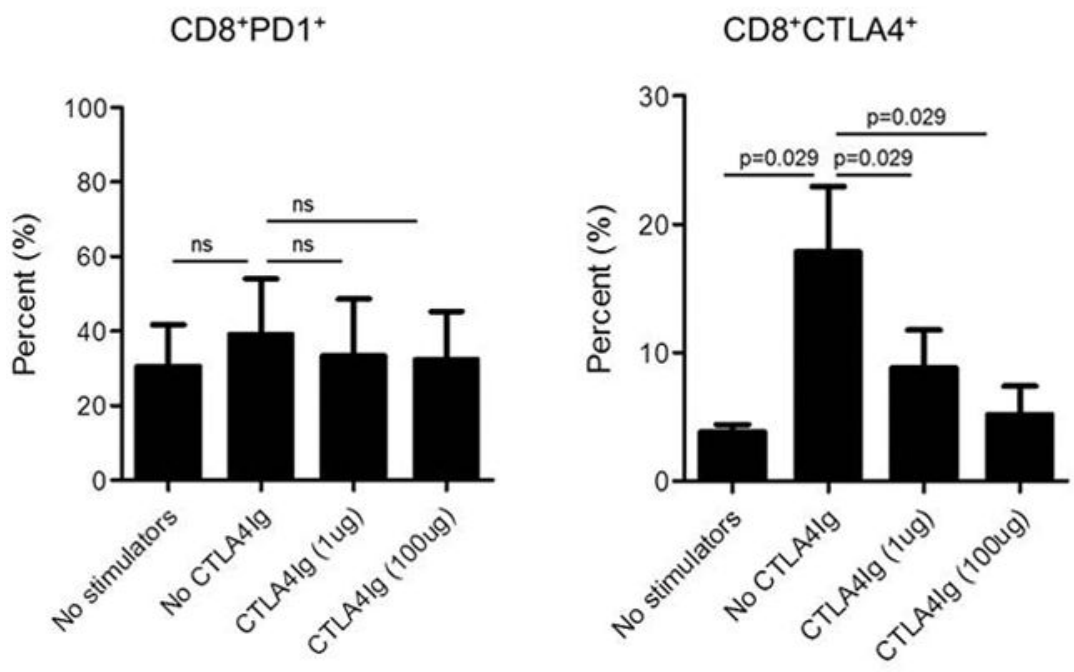

FIGURE 4.

Effect of CTLA4Ig on PD1 and CTLA4 expression by allostimulated normal monkey CD8 ${ }^{+}$ T cells. (A) CTLA4Ig inhibits total CD8 ${ }^{+} \mathrm{T}$ cell, CTLA4 ${ }^{+} \mathrm{CD} 8^{+} \mathrm{T}$ cell and $\mathrm{PD} 1^{+} \mathrm{CD} 8^{+} \mathrm{T}$ cell proliferation in a concentration-dependent manner. CFSE dilution and percentages of 
$\mathrm{CTLA}^{+}$and $\mathrm{PD} 1^{+}$populations were determined after gating on $\mathrm{CD} 8^{+} \mathrm{T}$ cells. (B) Percentages of $\mathrm{CD} 8^{+} \mathrm{PD} 1^{+}$and $\mathrm{CD} 8^{+} \mathrm{CTLA} 4^{+} \mathrm{T}$ cells following allostimulation in the absence or presence of CTLA4Ig. Responder PBMC were co-cultured with allogeneic T cell-depleted stimulator PBMC in CFSE-MLR for 5 days, in the absence or presence of CTLA4Ig (1 or $100 \mu \mathrm{g} / \mathrm{ml})$. Bars represent means +1 SD ( $\mathrm{n}=5$ independent experiments); ns=not significant. 
Figure 5A

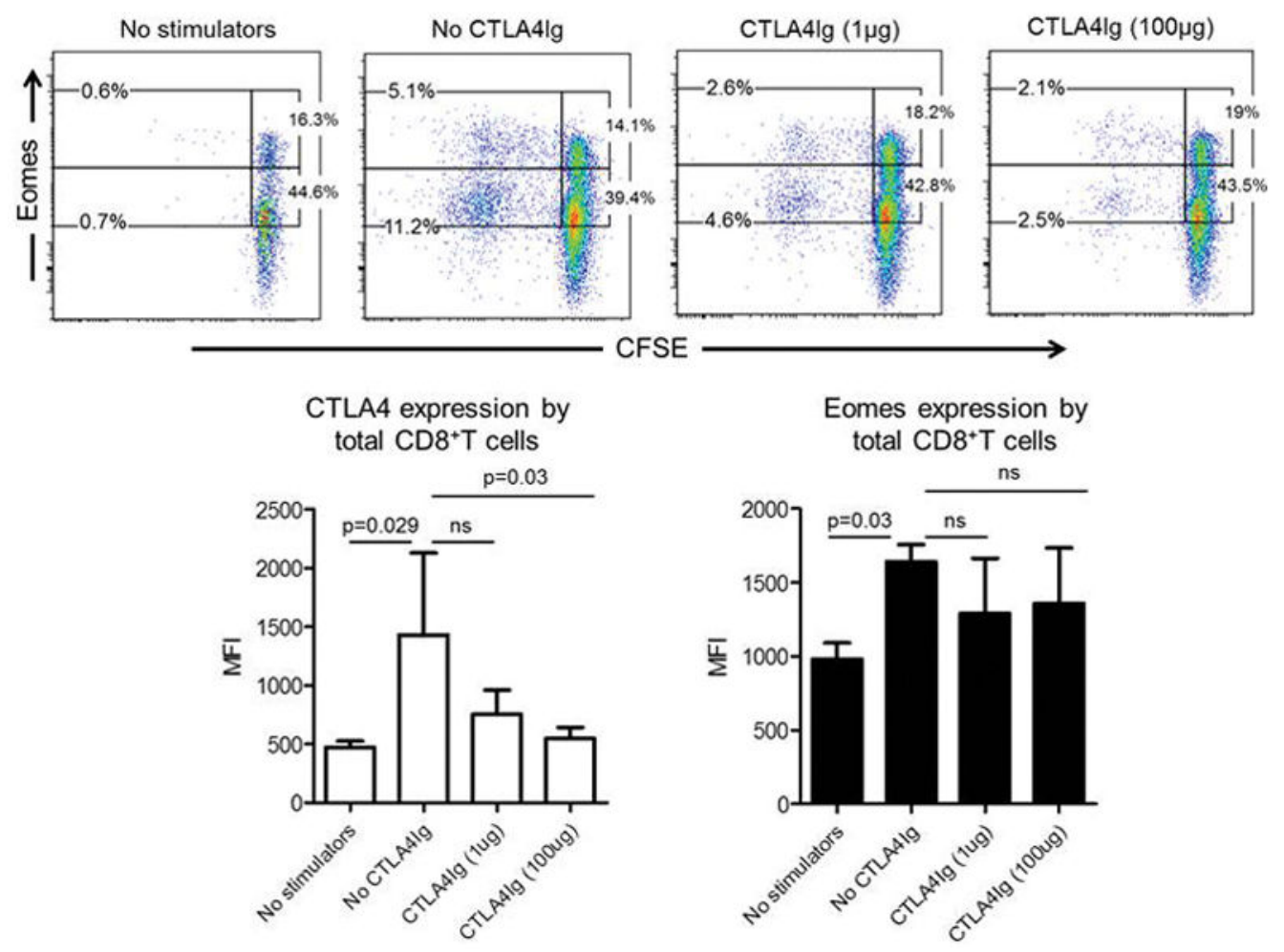

Figure 5B
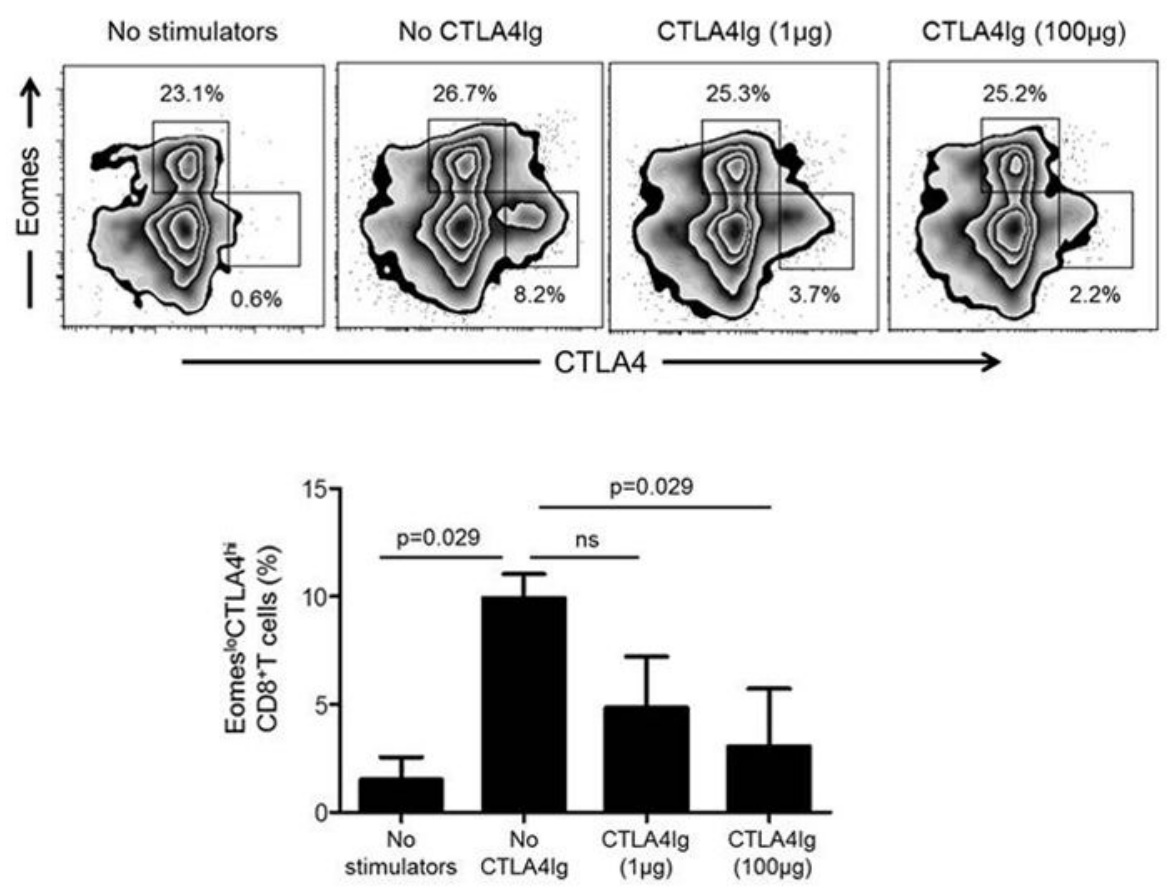

Transplantation. Author manuscript; available in PMC 2017 January 01. 
FIGURE 5.

CTLA4Ig does not reduce Eomes expression compared to CTLA4 expression by allostimulated normal monkey $\mathrm{CD}^{+} \mathrm{T}$ cells. (A) Proliferation of Eomes ${ }^{\text {lo }}$ and Eomes ${ }^{\text {hi }}$ normal monkey $\mathrm{CD}^{+} \mathrm{T}$ cells following allo-stimulation in MLR, in the presence or absence of CTLA4Ig. Representative data from one experiment are shown (top). CTLA4 and Eomes expression by $\mathrm{CD}^{+} \mathrm{T}$ cells following allostimulation is also shown (bottom panels).

Representative and mean values +1 SD of 4 independent experiments are shown; ns=not significant. (B) Frequencies of Eomes ${ }^{\text {lo }}$ CTLA $4{ }^{\text {hi }}$ and Eomes ${ }^{\text {hi }}$ CTLA4 ${ }^{\text {lo }} \mathrm{CD} 8^{+} \mathrm{T}$ cells following allostimulation in the absence or presence of CTLA4Ig. Representative data (top) and means +1 SD of 4 independent experiments are shown (bottom). 
Figure 6A

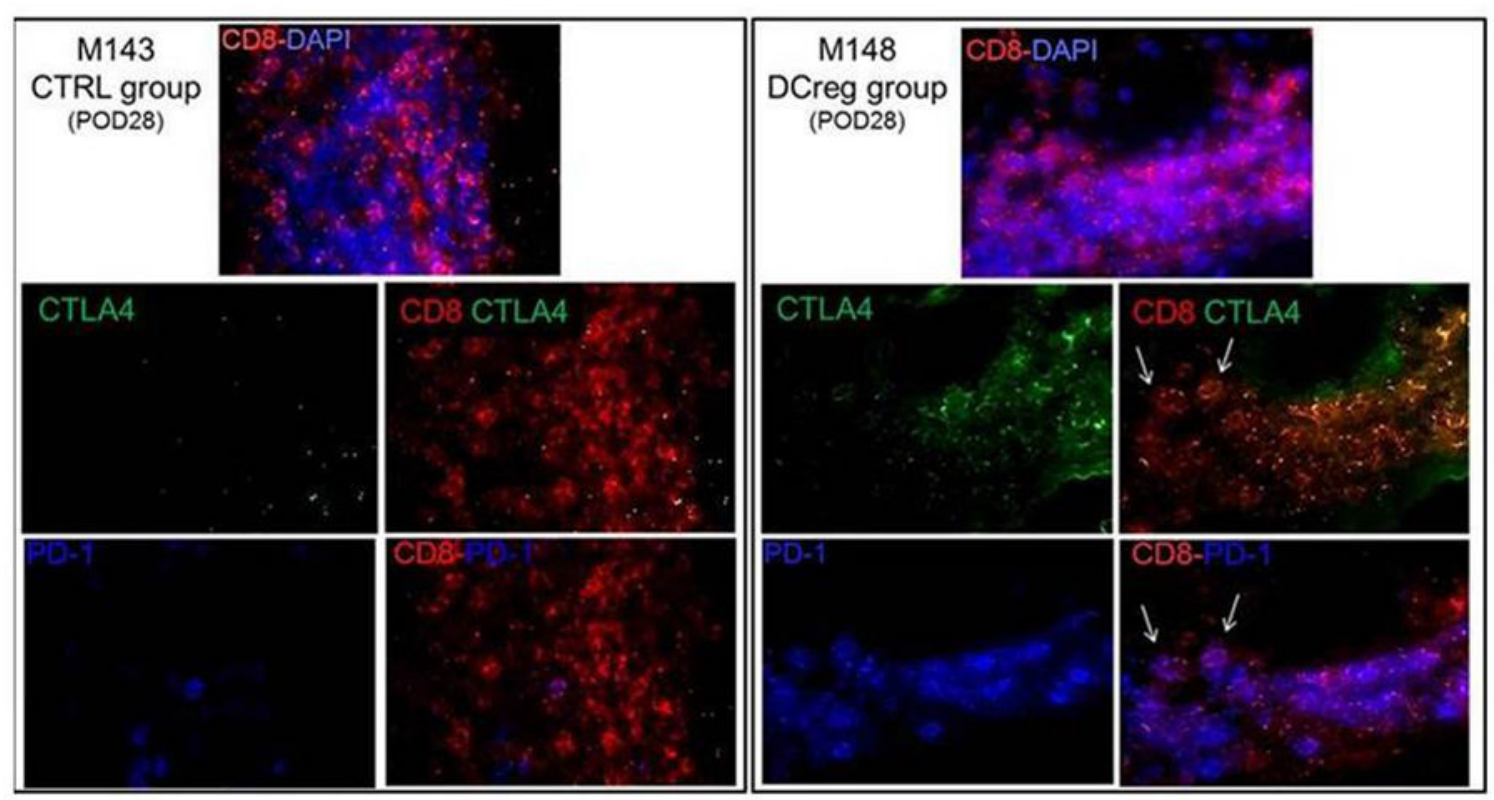

Figure 6B
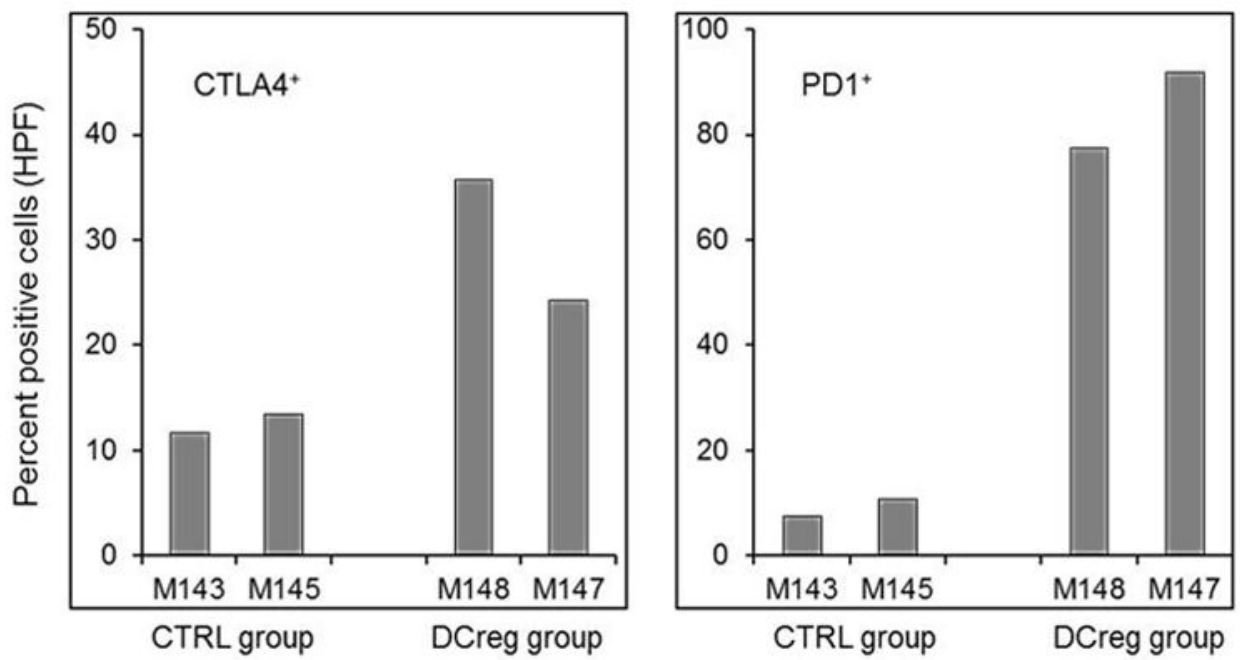

FIGURE 6.

CTLA4 and PD1 expression by graft-infiltrating $\mathrm{CD}^{+} \mathrm{T}$ cells in rhesus monkey kidney transplant recipients. (A) CTLA4 (CD152) and PD1 (CD279) expression by CD8 ${ }^{+} \mathrm{T}$ cells was examined by immunofluorescence staining. Graft tissue from a representative monkey (M143) in the control (CTRL) group (treated with CTLA4Ig and rapamycin) at the time of graft rejection (postoperative day [POD]28) is shown. Tissue from a graft recipient in the group that also received DCreg (M148) was obtained by open kidney graft biopsy, also on POD 28. Co-localization of CTLA4 (green) and PD1 (blue) with CD8 ${ }^{+} \mathrm{T}$ cells (in red) is 
shown (white arrows) in the middle and bottom panels, respectively. Nuclei were stained with DAPI (blue; upper panels). Slides were examined with a Nikon Eclipse E800 microscope equipped with a CCD camera (Nikon). Leukocyte infiltrates were quantified at 200x on at least 3 sections per allograft, with MetaMorph Offline 7.7.50n software. (B) Numbers of $\mathrm{CTLA} 4^{+}$and $\mathrm{PD} 1^{+} \mathrm{CD} 8^{+} \mathrm{T}$ cells per high power field (HPF) in the allograft tissue of control (CTRL) and DCreg-treated monkeys. 
Figure 7A

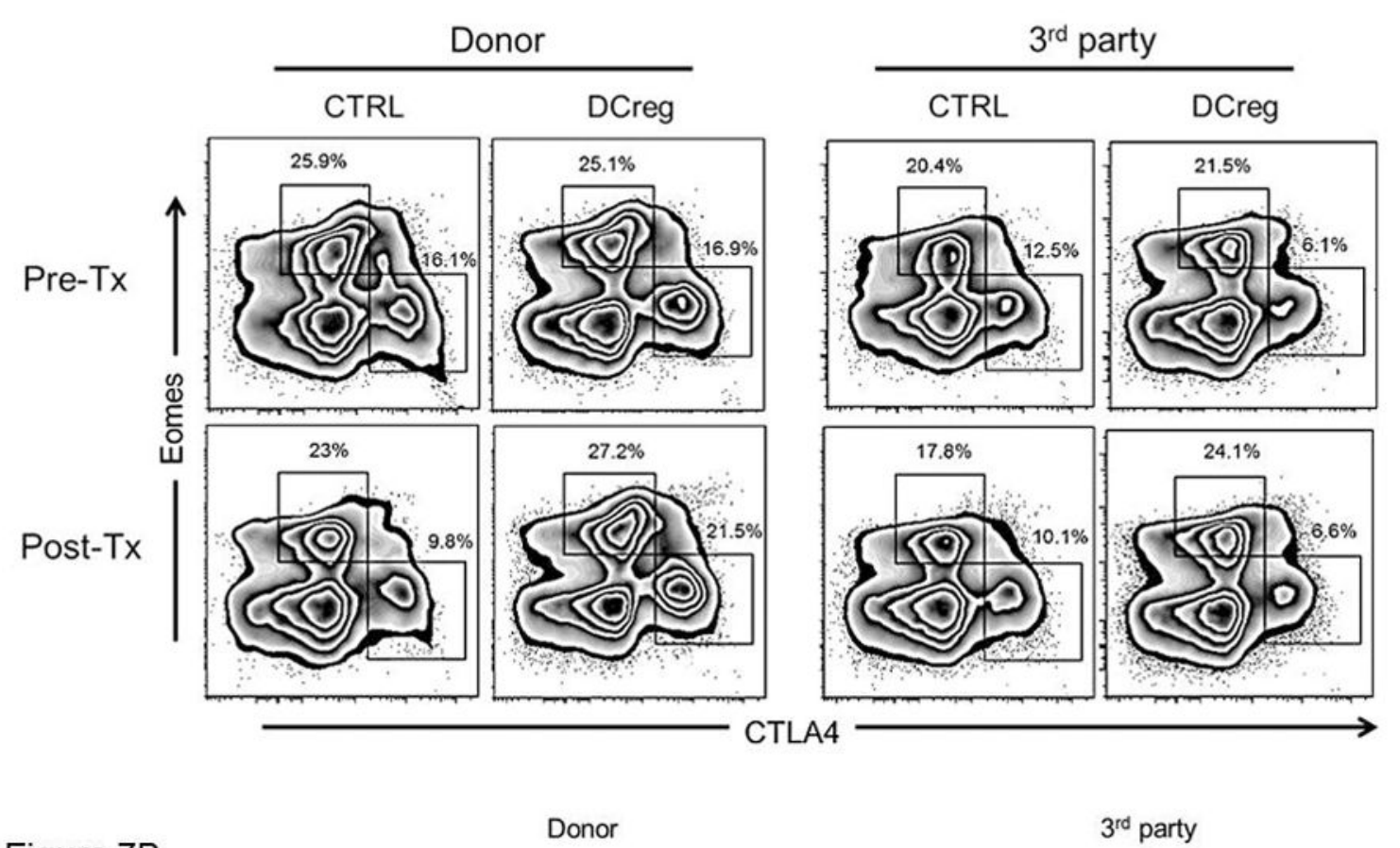

Figure 7B
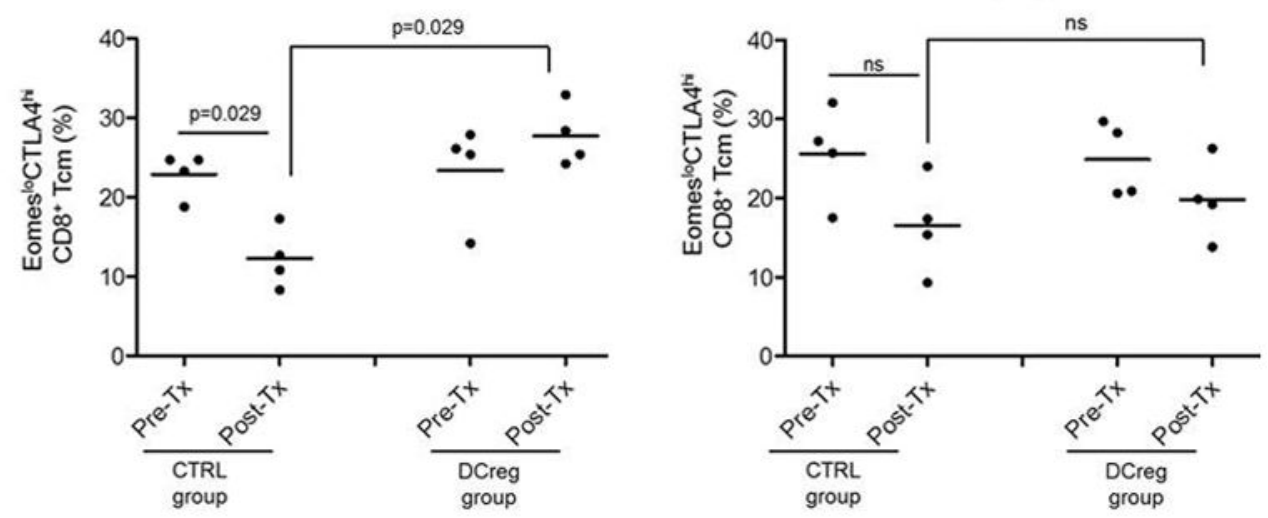

Donor

$3^{\text {rd }}$ party
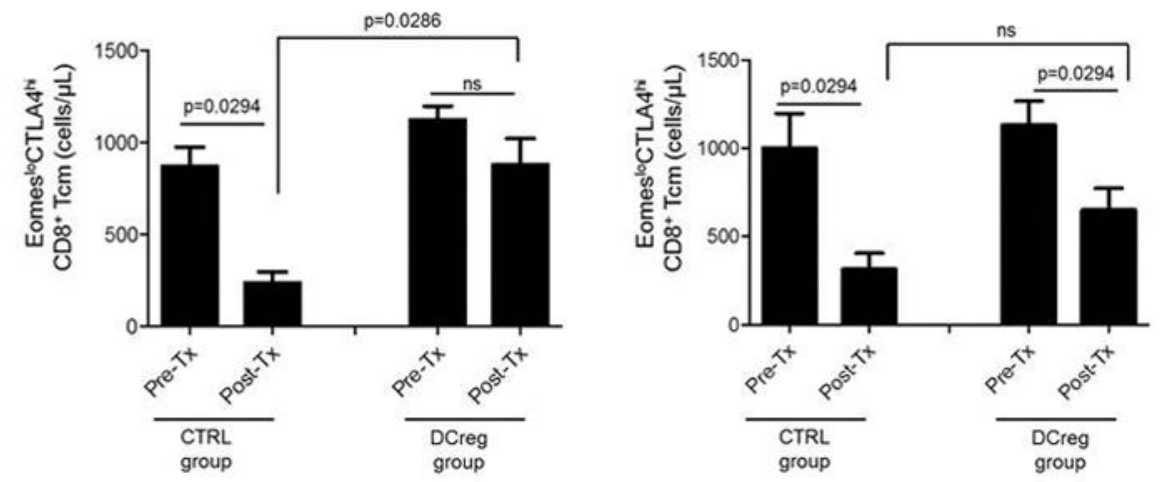

FIGURE 7.

Transplantation. Author manuscript; available in PMC 2017 January 01. 
DCreg infusion spares reductions in donor-specific Eomes ${ }^{\mathrm{lo}} \mathrm{CTLA} 4{ }^{\mathrm{hi}} \mathrm{CD} 8^{+} \mathrm{Tcm}$ in CTLA4Ig-treated renal allograft recipients. (A) Incidences of Eomes ${ }^{10}$ CTLA $4{ }^{\text {hi }}$ and Eomes ${ }^{\text {hi }} \mathrm{CTLA} 4{ }^{\text {lo }} \mathrm{CD} 8^{+} \mathrm{T}$ cells in response to donor or $3^{\text {rd }}$ party stimulation, before transplant and on day 28 post-transplant in representative control (CTRL) and DCreg-treated monkeys. (B) Percentages (top) and absolute numbers $\pm 1 \mathrm{SD}$ (bottom) from 4 allograft recipients in each group. Responder PBMC were co-cultured with donor or third party $\mathrm{T}$ cell-depleted PBMC for 5 days. Percentages and absolute numbers of Eomes ${ }^{\mathrm{lo}} \mathrm{CTLA} 4{ }^{\mathrm{hi}}$ were determined after gating on $\mathrm{CD} 8^{+} \mathrm{T}$ cells. $\mathrm{ns}=$ not significant. 